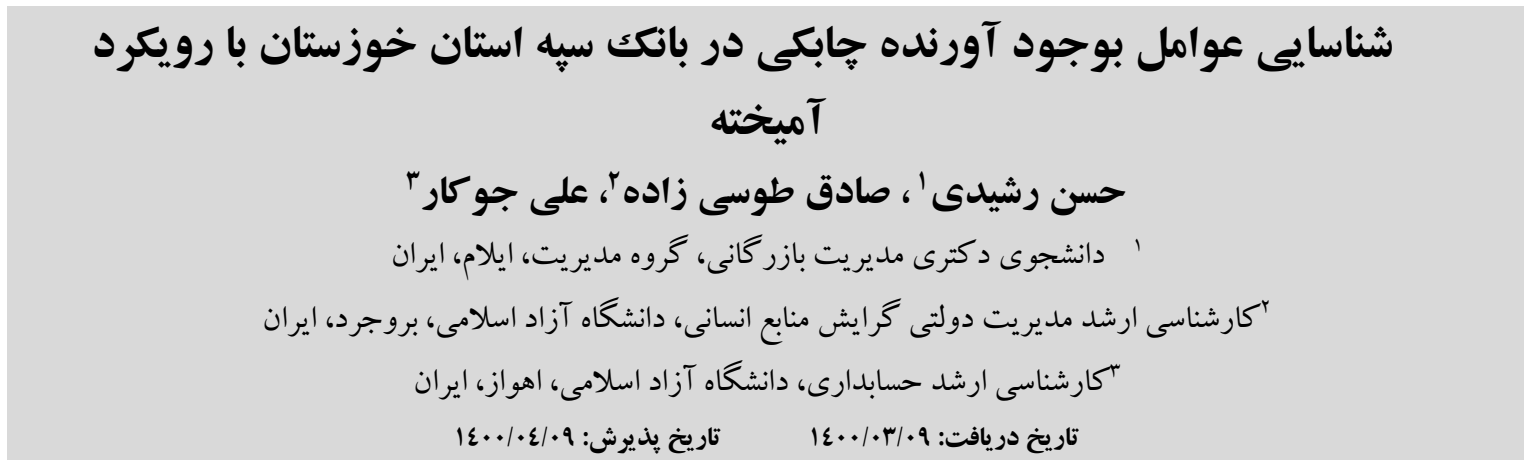

\title{
Identifying the factors that create agility in Sepah Bank in Khuzestan province with a mixed approach
}

\author{
Hassan Rashidi ${ }^{1}$, Sadegh Toosizadeh ${ }^{2}$, Ali Jokar ${ }^{3}$ \\ ${ }^{1} \mathrm{PhD}$ student in Business Management, Department of Management, Ilam, Iran \\ ${ }^{2}$ Master of Public Management, Human Resources, Islamic Azad University, Boroujerd, Iran \\ ${ }^{3}$ Master of Accounting, Islamic Azad University, Ahvaz, Iran
}

Received: (30/05/2021) Accepted: (29/06/2021)

شناسه يكتا

\begin{abstract}
Nowadays, the competition between banks and financial institutions for attracting, retaining and retaining customers has intensified and there are many methods such as advertising, facilities, deposit interest and so on. But one of the methods that, as an important and vital factor, helps in this direction, which can establish the organization among competitors both in terms of cost reduction and in the long run, is the agility of the organization. The aim of the present study was to identify the factors that create organizational agility in Sepah Bank in Khuzestan province with a mixed approach. The research method with a mixed approach (qualitative-quantitative) which in the qualitative part in terms of purpose, fundamental and exploratory type and in the quantitative part in terms of purpose, is applied and descriptive-survey type. The statistical population of the research in the qualitative part includes 15 experts and in the quantitative part all the employees of Sepah Bank in Khuzestan province, which according to Cochran's formula was 235 people. After analyzing the data in the qualitative section using Max QDE software version 2020 and in the quantitative section with SPSS and Amos statistical software, it was determined that: In the findings of the qualitative section, 16 components and 5 categories (Product variety, training, facilities, communication and convenience) were obtained. Also, in the findings of the quantitative section, the variables of product diversity, training, facilities and ease had a positive and significant effect on organizational agility, but the effect of communication variable on organizational agility was not confirmed.
\end{abstract}

Keywords

Organizational agility, customer, mixed approach,

Sepah Bank Khuzestan.topsis.

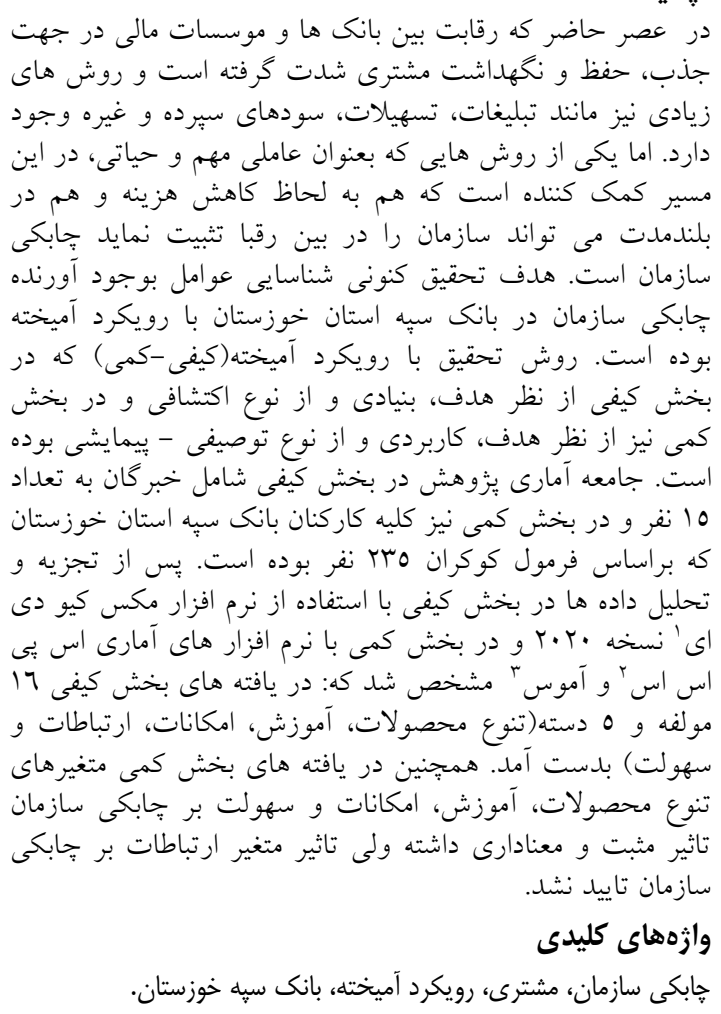

\footnotetext{
${ }^{1}$ Maxqda

2 spss

${ }^{3}$ Amos
} 
حابكى سازمانى توانايى شركت در ياسخ به تغييرات و تحر كات

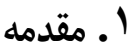

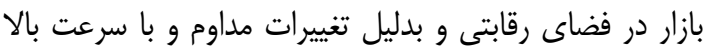
جهت رضايت مشترى مى باشد. حابكى سازمانى نيازهاى

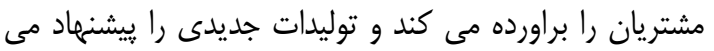

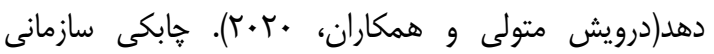

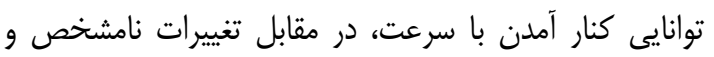

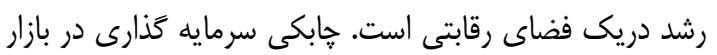

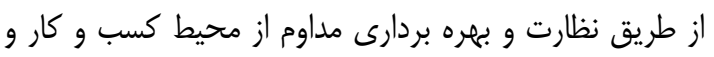

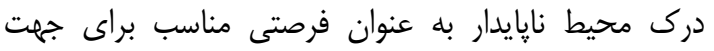

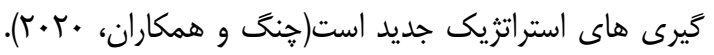

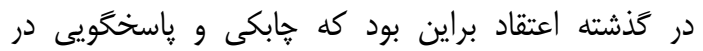
استراتزى منعطف مى تواند از طريق فناورى هاى بيشرفته

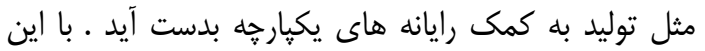

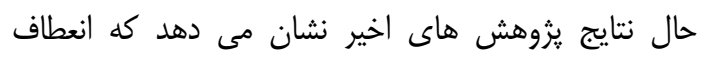

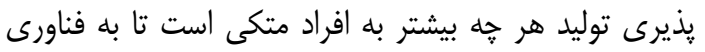

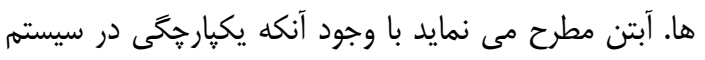

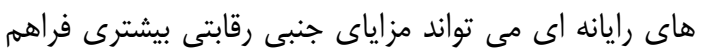

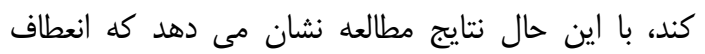
يذيرى عملياتى عمدتا از طريق مجريان عملياتى كارخانه و بـانه

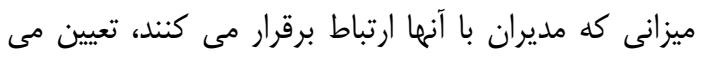

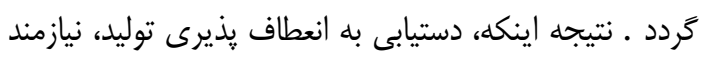

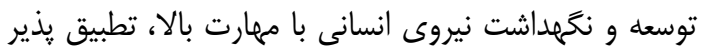

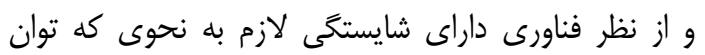

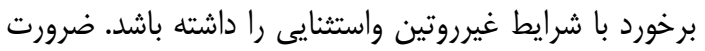

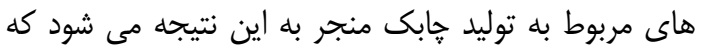

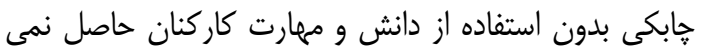

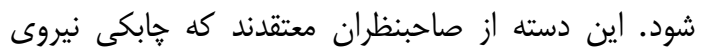
انسانى ممكن است طيف كسترده اي از مزايا و منافع را به يه

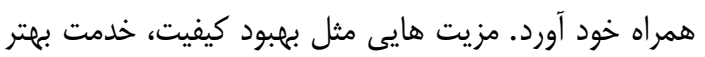

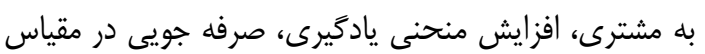

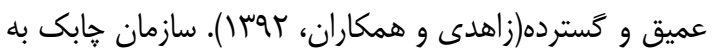
عنوان آرمانى براى سازمان هاى قرن بيست و يكان يكم طرفداران

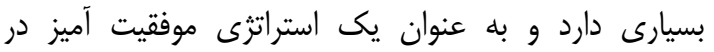

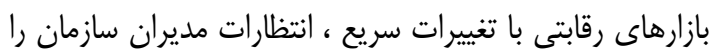

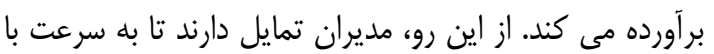

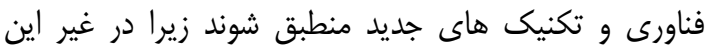
صورت از ديخران عقب مانده و محصولات و شركت هائ دائ

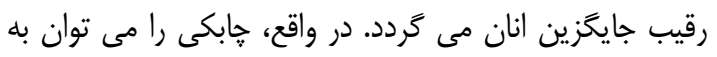

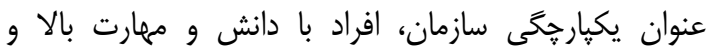
تكنولوزى هاى ييشرفته براى رسيدن به نوآورى و و همكارى

امروزه سازمان ها با محيطى مواجه هستند كه نياز است فعاليتها و استراتزى هاى خود را به سرعت با با آن تطبيق آنايق

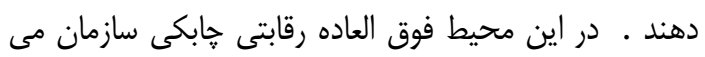

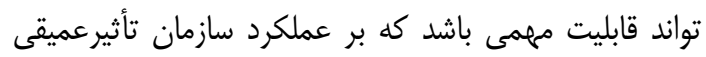
بكذارد . براساس تحقيقات شركت ها قادر هستند با باسخ ناسخ كويى سريع و نوآورانه و تغيير در كسب و كار خود در محيط،

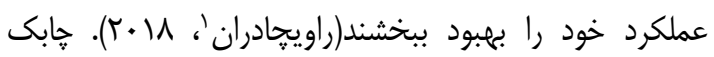

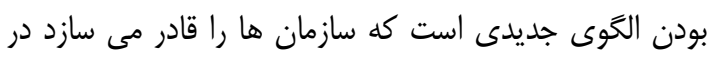

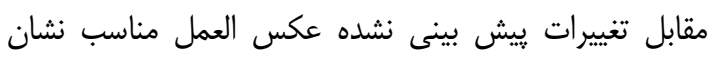

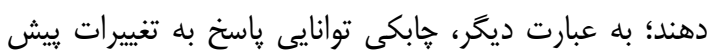

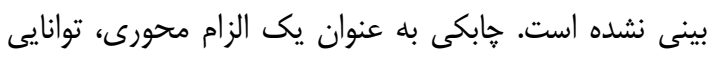

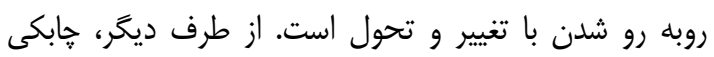

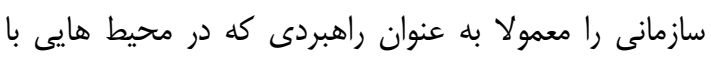

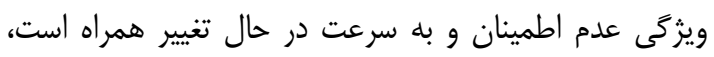
توصيف مى كنند. קابكى را بايد از مفهوم مختصر انعطان

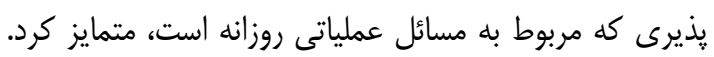

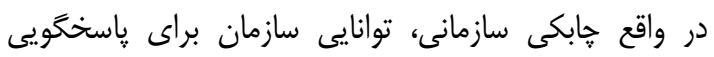

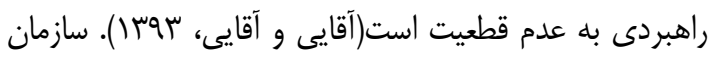

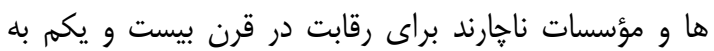

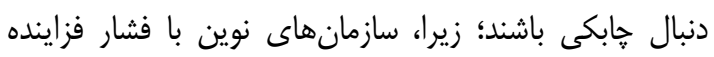

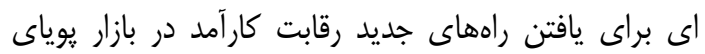

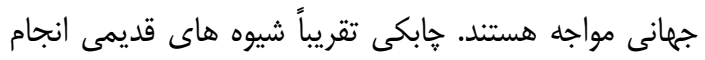
كار را كه مناسب با شرايط ايستاى عمليات سنتى بودند،

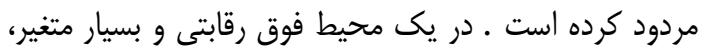

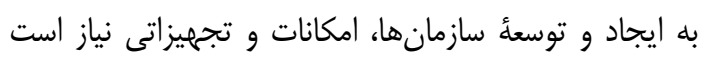
كه بسيار منعطف باشند و حساسيت بسيار زيادى نسبت بله بهان

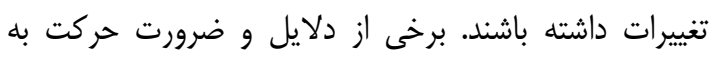
سمت خابكى سازمان را مى توان رقابت شديد درات درات محيط

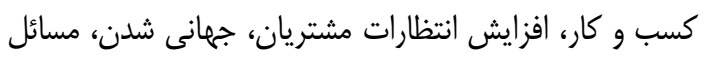
فرهنكى و اجتماعى، محدوديت نيروى انسانى ماهر، فناورى

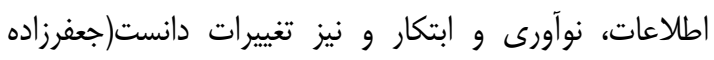

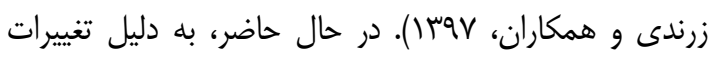

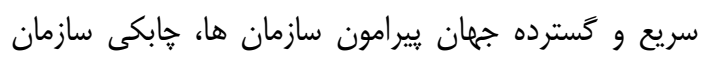

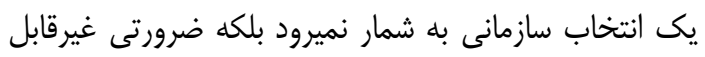

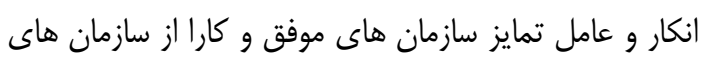
غير كارا شمرده مى شود(قانع عبادى و همكاران، رهوسار).

\footnotetext{
${ }^{1}$ Ravichandran
} 
رسد بانك هاى دولتى كشور به دلايل مختلفى از جمله

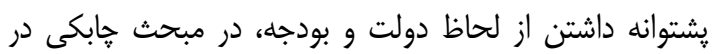

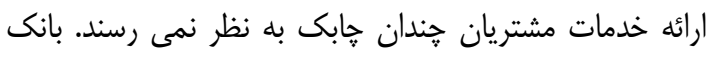

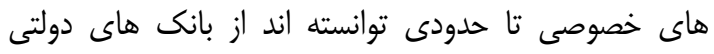

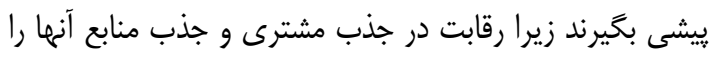

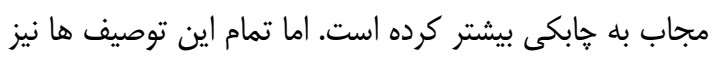

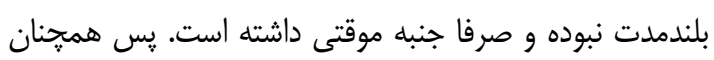

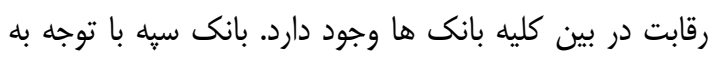

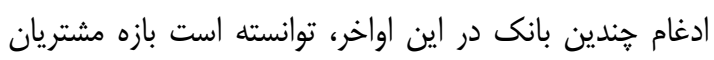

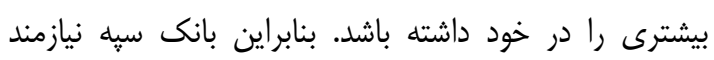

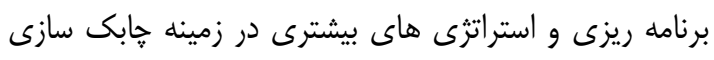

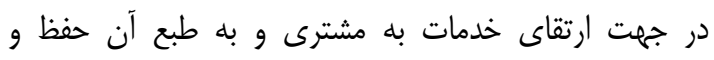

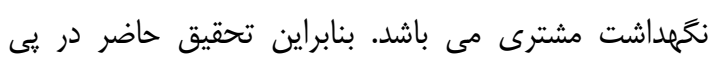

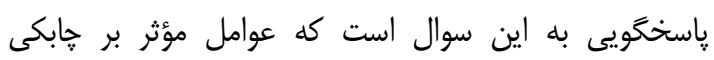

سازمان در بانك سيه استان خوزستان كدامند؟ كال

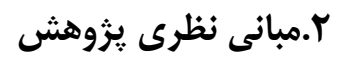

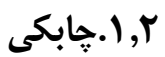

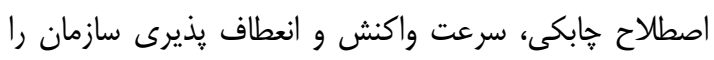

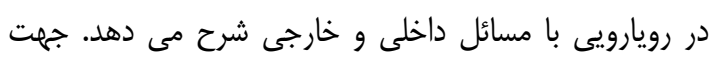

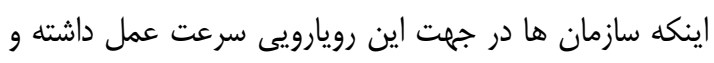

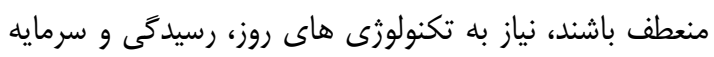

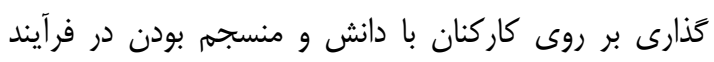

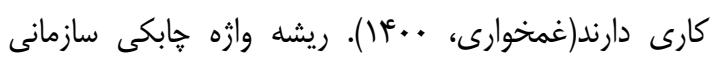

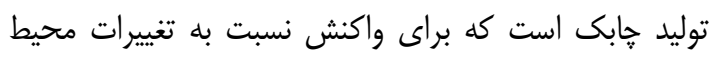

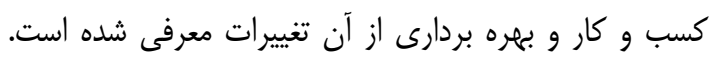

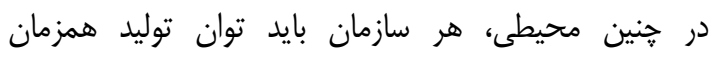
محصولات متفاوت و با طول عمر كوتاه، طراحى مجان مجدان

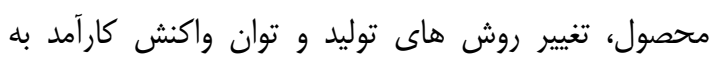

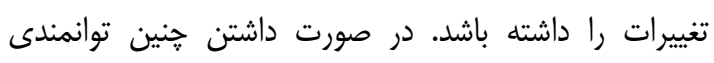

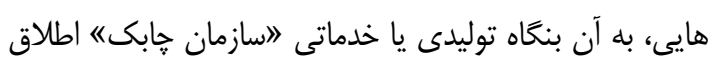

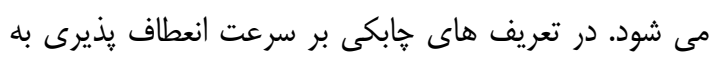

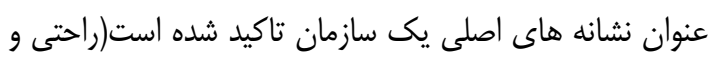

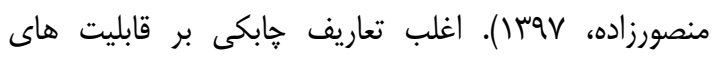

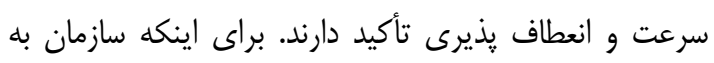

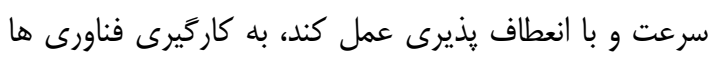

در ياسخ به نيازهاى مشتريان در نظر گرفت. به همين خاطر،

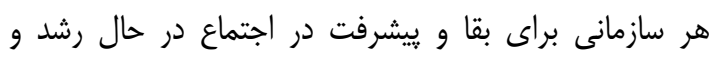

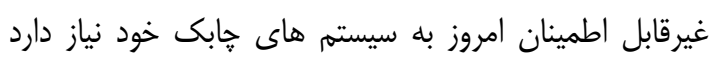

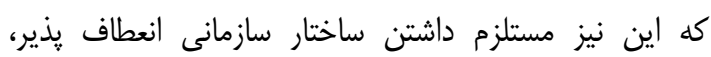

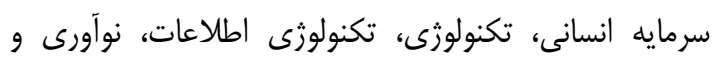

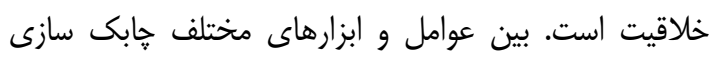

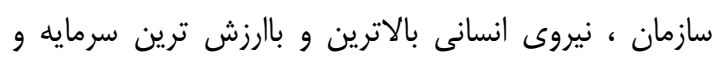

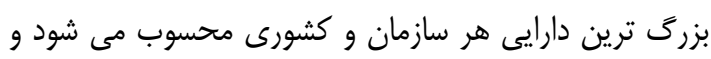

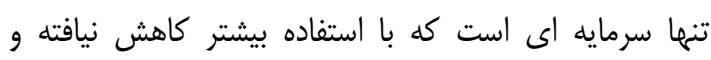

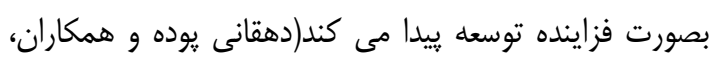

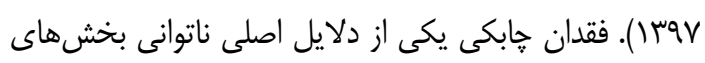

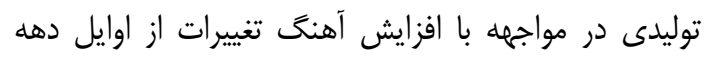

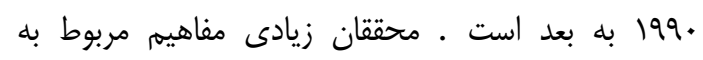

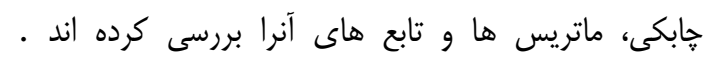

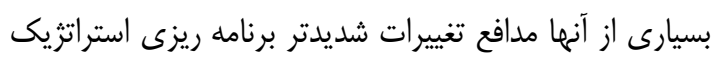

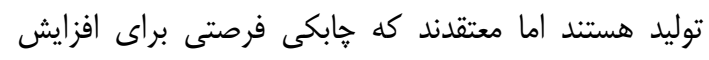

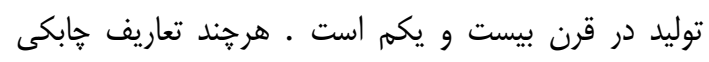

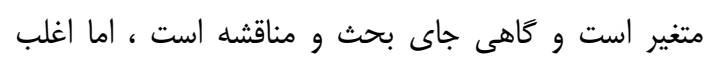

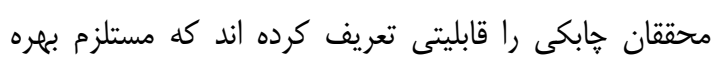

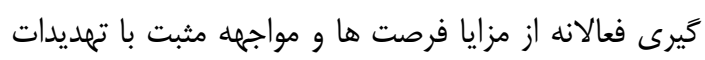

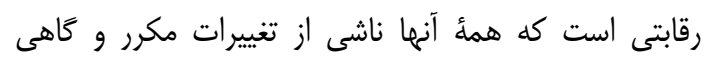

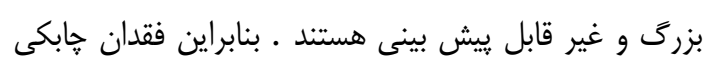

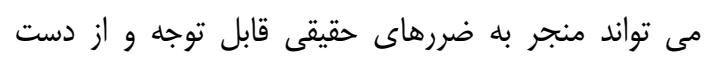

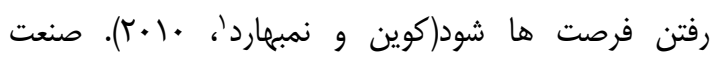

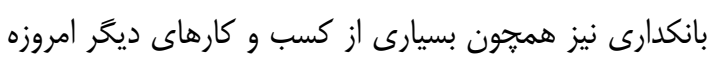

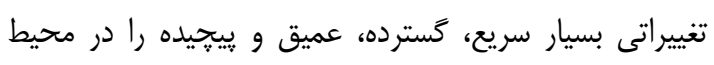

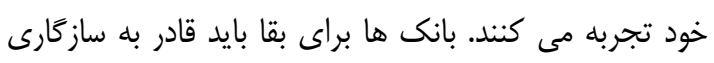

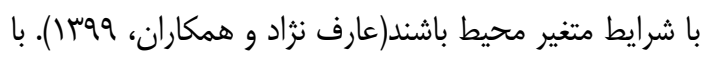

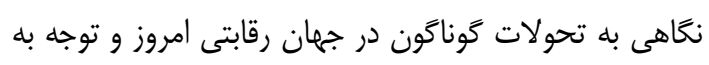

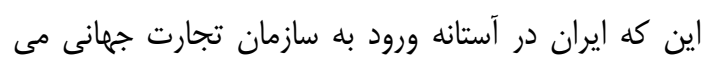

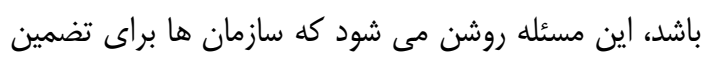

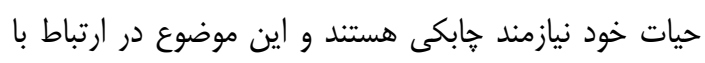

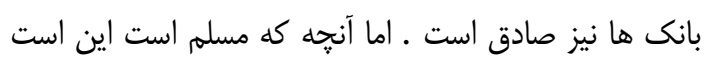

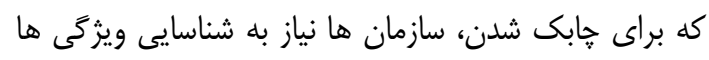

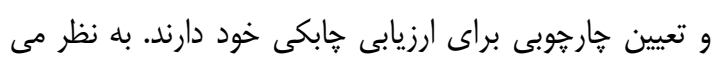

' Qin \& Nembhard 
انعطاف بذيرى منابع انسانى در صنعت بانكدارى به اين نتيجه دست يافتند كه مؤلفه هاى انعطاف يذيرى وظيفه ائ مئ مهارتى و رفتارى به ترتيب از بيشترين نقش در تبيين حابكى سازمان

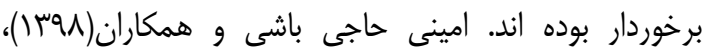

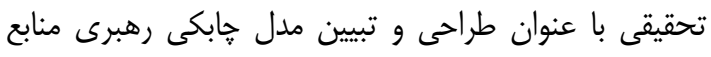

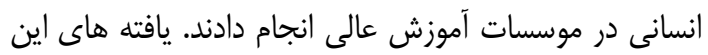
تحقيق حاصل مصاحبه نيمه ساخت يافته با ها نفر از خبركان

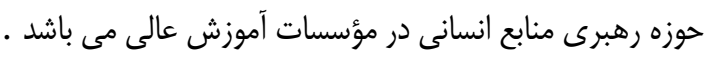

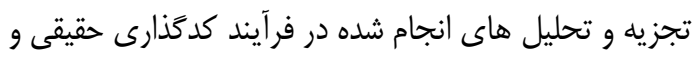

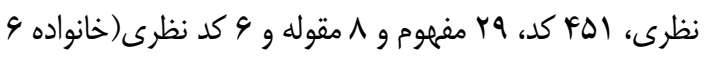
سى ها ) را نشان داد كه منجر به ظهور مدل نهايى يزوهش شد ـ يافته هاى اين يثوهش شامل : ا-شناسايى مؤلفه هاى جابكى رهبرى منابع انسانى ، Y -يافتن نتايج و يبامدهاى حاصل از خابكى رهبرى منابع انسانى ، بـ - شناسايى روابط بين

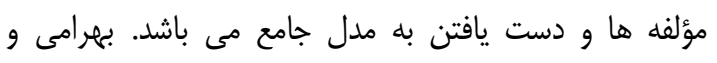
كريمى كوارشكى( در تعميرات اساسى با روش مدلسازى ساختارى تفسيرى (مورد

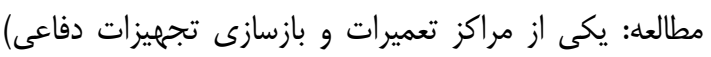

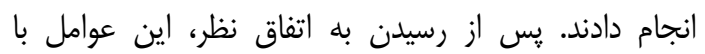
رويكرد مد نظر تجزيه و تحليل شده و در شش سطح طبل نبله

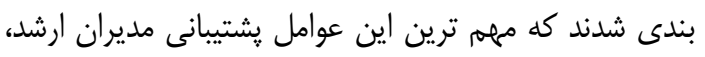

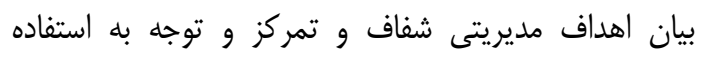

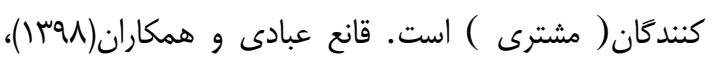

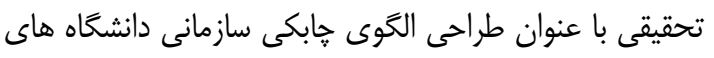

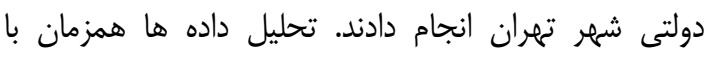

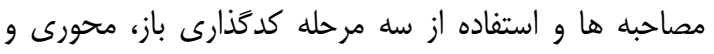

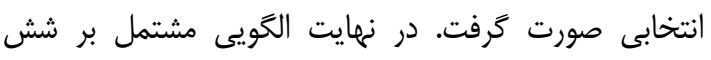

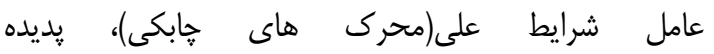

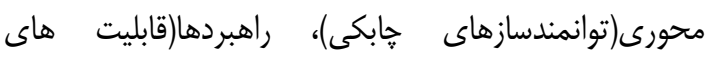

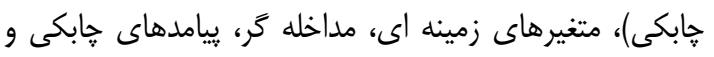

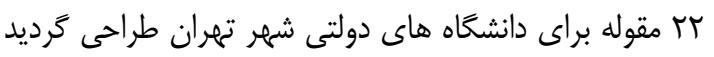

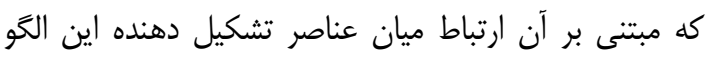

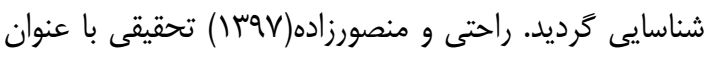

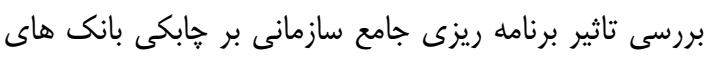

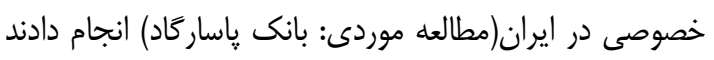

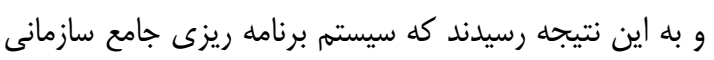

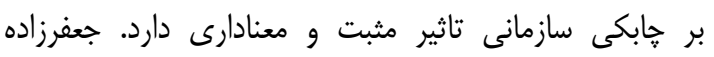

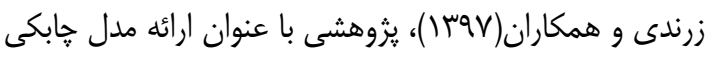
سازمانى بر مبناى فناورى اطلاعات در سازمان هاى ورزشى باري
و سيستم هاى اطلاعاتى به روز، سرمايه كذارى روى كاركنان

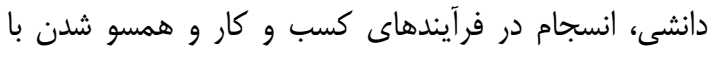

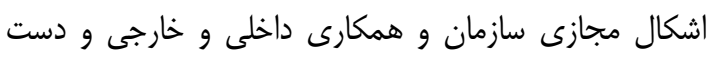

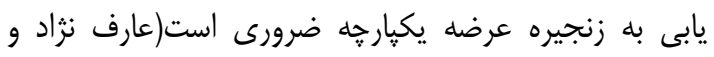

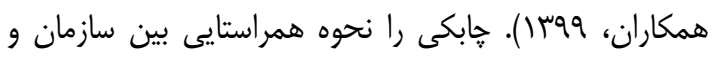

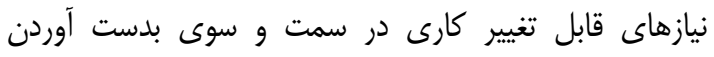

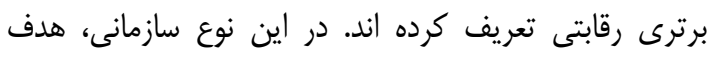

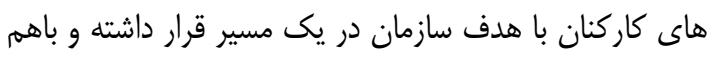

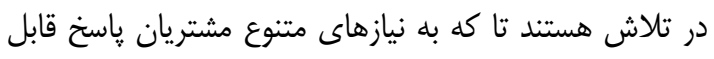

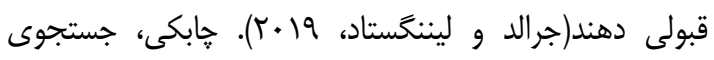

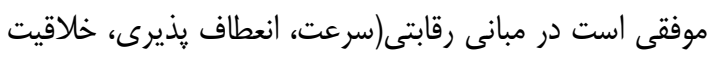

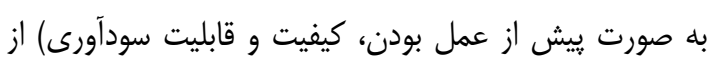

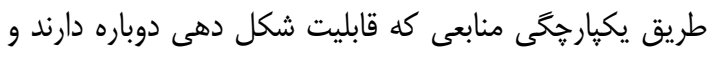

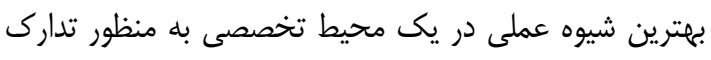

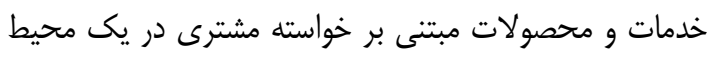

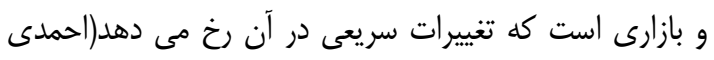

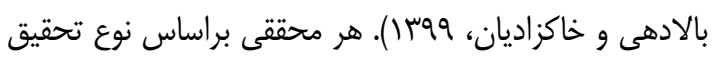

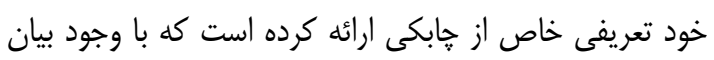

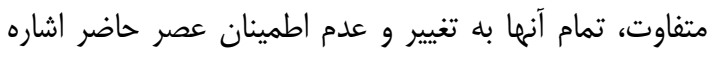

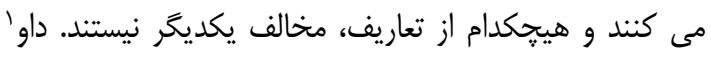

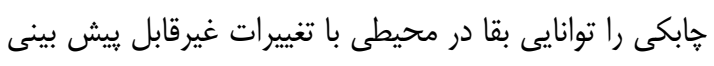

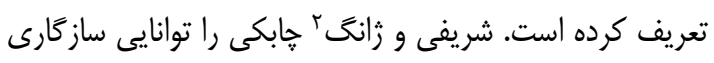

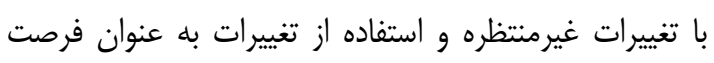

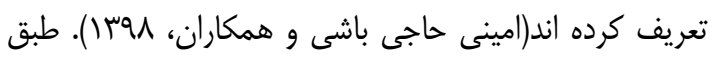

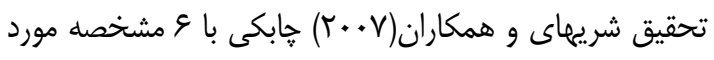

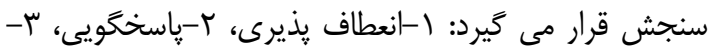

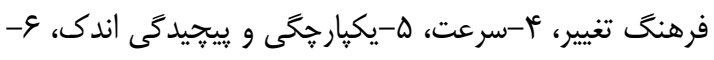
همكارى متقابل(طبرسا، هوجسا).

\section{". بيشينه تجربى يزوهش}

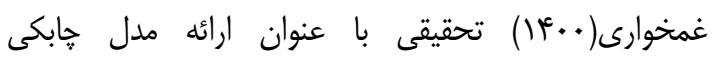

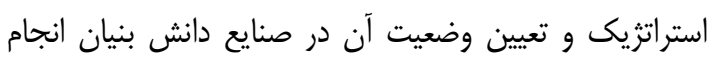

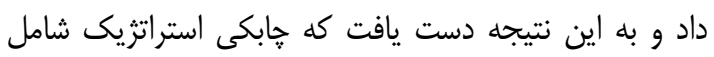

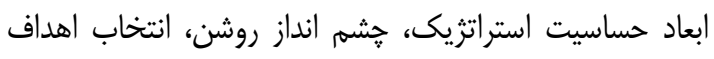

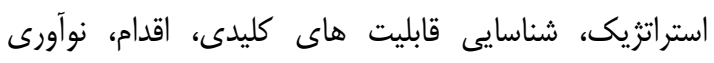

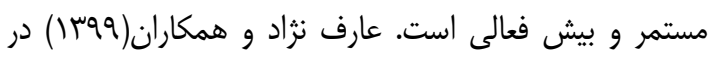
تحقيقى با عنوان مدل ارتقاى خابكى سازمانى مبتنى بر بران هان

'Dove

r Sharifi\& Zhang 
مواجهه با عدم اطمينانى را بإيين بياورند، بلكه كام در مسير

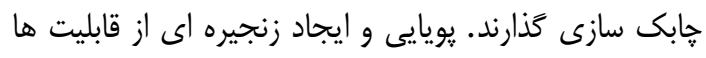

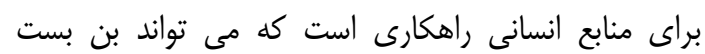

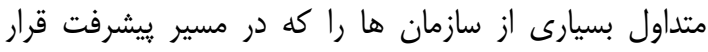

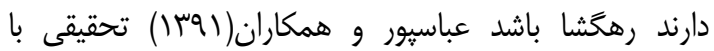

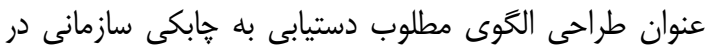

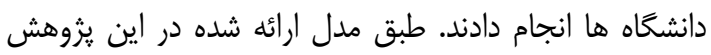
حابكى در دانشخاه ها از عأ مولفه تشكيل شده است كها

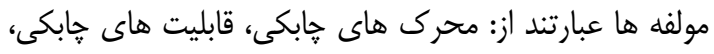

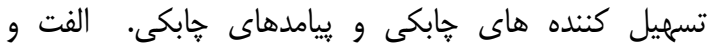
زنجيرجى(

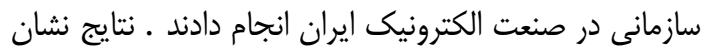

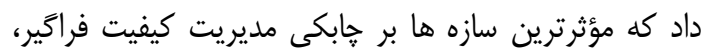

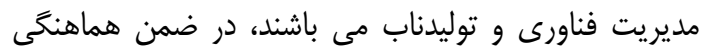

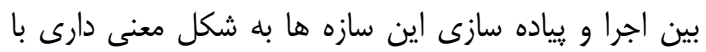

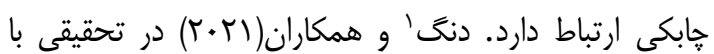

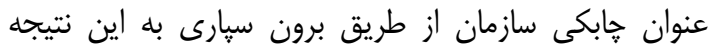

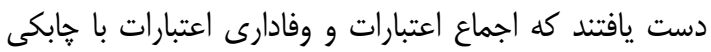

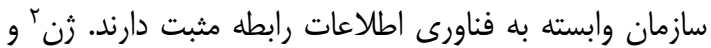

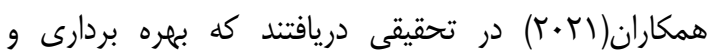

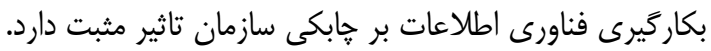

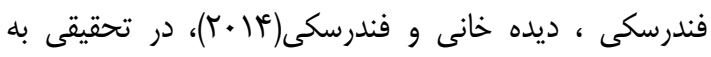
منظور شناسايى و رتبه بندى عوامل هابكى با با تكنيك فرايند

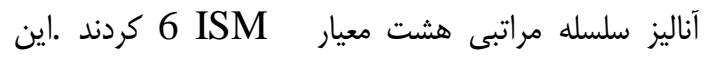
عوامل با استفاده از نظر خبر كان و روش معيار كه شامل 32 شاخص بود را به عنوان عوامل خابكى شناسايى كردند ـ ـاين

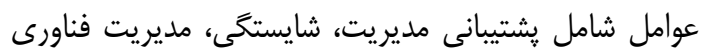
اطلاعات، آموزش و كسب مهارت، مديريت منابع انسانى، كار

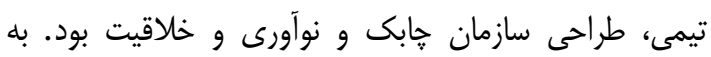

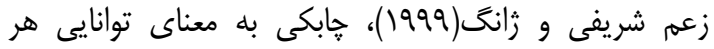

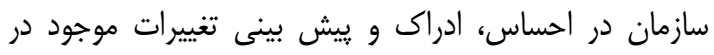
محيط كسب و كار است. عمده ترين نتايج يزوهش بران به اين اين قرار است: براى دستيابى به هابكى سازمانى عانى عوامل ساختار

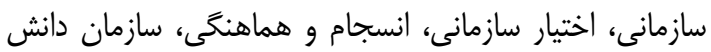

\footnotetext{
${ }^{1}$ Deng

2 Zhen
}

ايران انجام دادند. يافته هاى حاصل از مصاحبه عميق، با

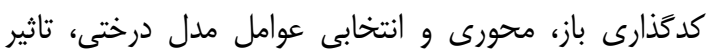
زيرساخت فناورى در سازمان هاى ورزشى بر خابكى سازمانى

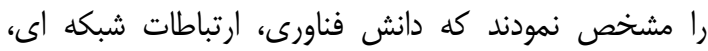

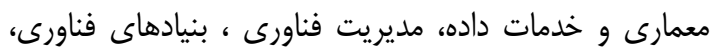

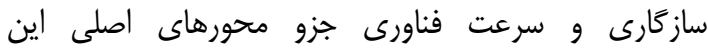
زيرساخت قلمداد شدند و بيش فرض

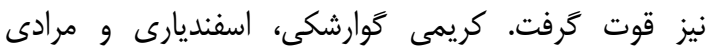

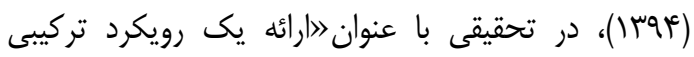
مبتنى بر تحليل شكاف و تكنيك توسعه عملكرد كيفيت

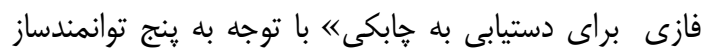

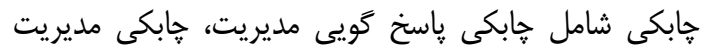

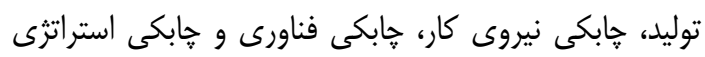

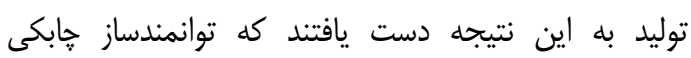

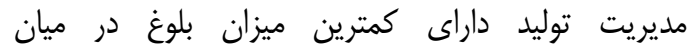

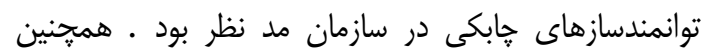

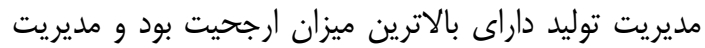

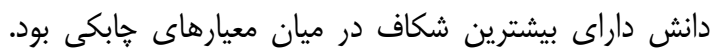

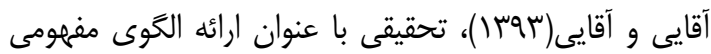

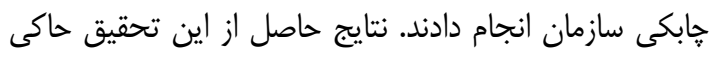

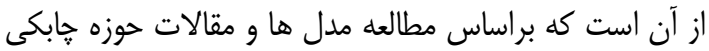

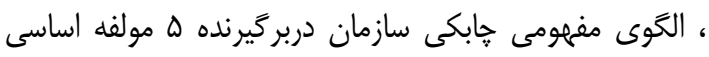
به صورت زير است: عوامل سازمانى، عوامل انسانى، عوامل

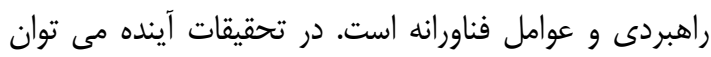
الكوى معرفى شده در اين تحقيق را در محيط عملى سازمان

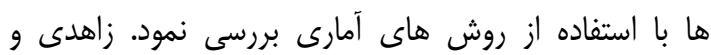

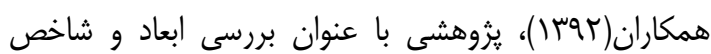
هاى قابليت هاى هابكى نيروى انسانى انجام دادند. در اين اين

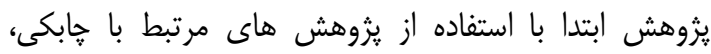
جارجوبى فراهم شده و سبس باروش دلفى خبر كان و وبا نمونه

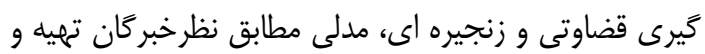

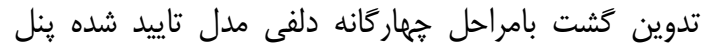
خبركان با ابعاد ينج كانه و شاخص هاى متان متعدد قابليت هاى

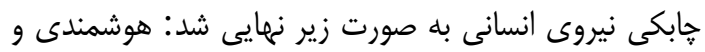

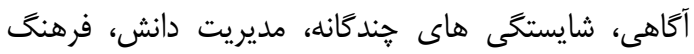
توانمند سازى، سيستم اطلاعات ـ تجهيز منابع انسانى به اين فاني قاليت ها موجب خواهد شد كه سازمان ها نه تنها ريسك الناني 
استفادهشده است. در ارزيابى درونى يس از انجام مصاحبه و و

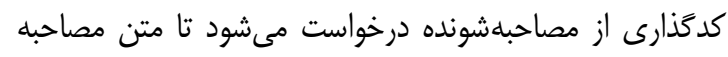

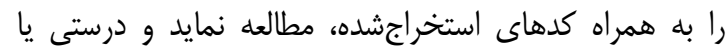

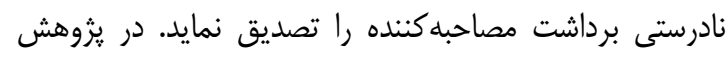

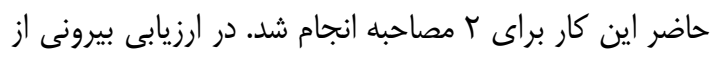

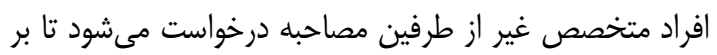
شيوه كدگذارى نظارت نمايد و درستى و نادرستى تحليل مصاحبه را تعيين نمايد. براى اين كار نيز نظر كارئ نائ نفر از اساتيد

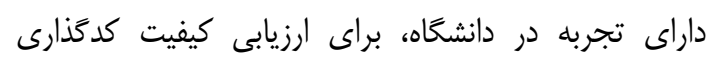

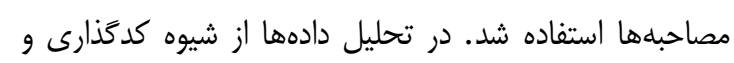

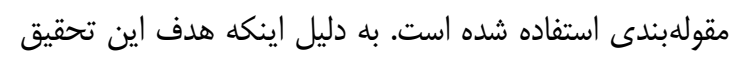

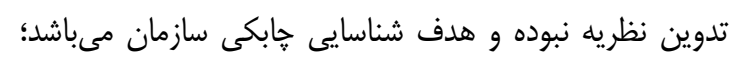

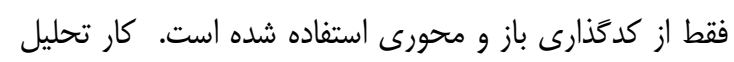

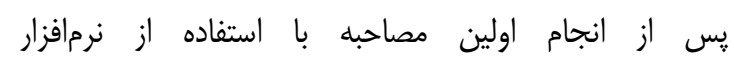

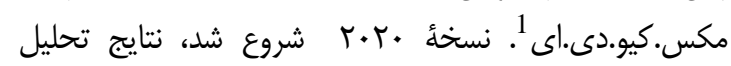

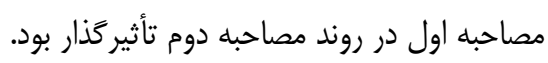

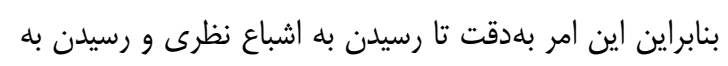

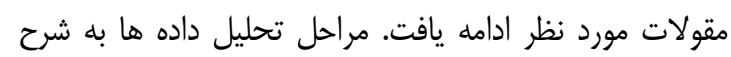

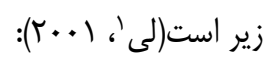

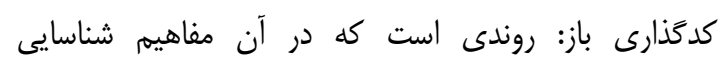

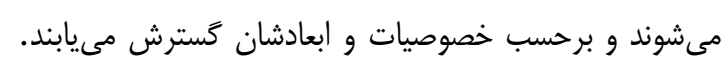

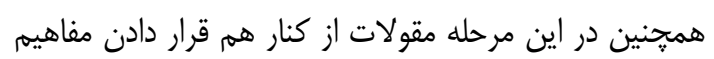
مشابه به دست مى آيند. كدكذارى محورى: كدگذارى محورى، فر آيند تبديل مفاهيم بله

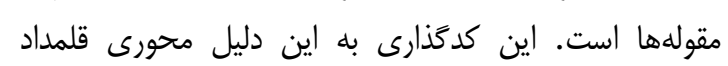

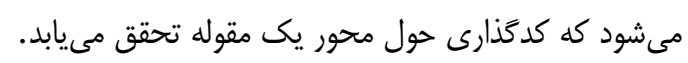

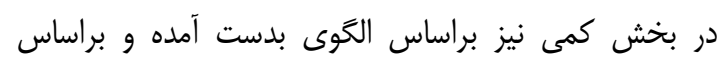

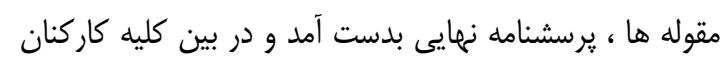

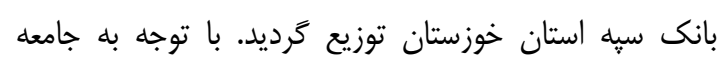

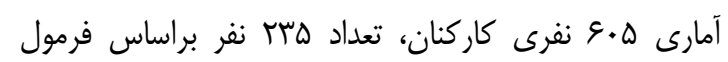

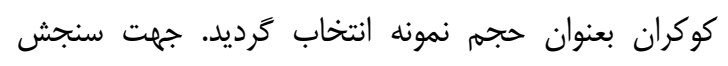

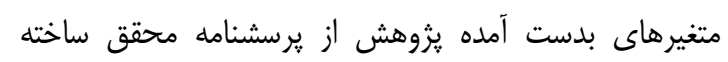

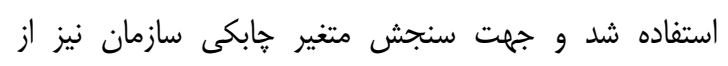

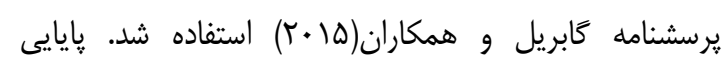

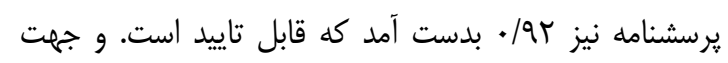

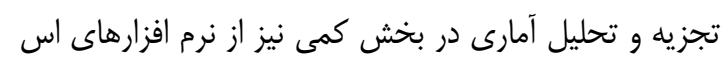

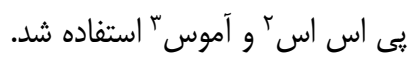

\footnotetext{
${ }^{1}$ Lee

2 spss

3 Amos
}

محور، شايستخى، سرعت، آموزش، فناورى ، مهندسى شغلى و

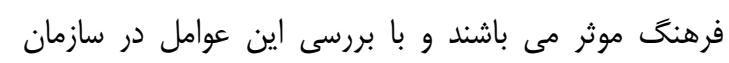

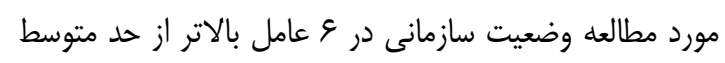
و در أ عامل بايين تر از حد متوسط قرار دارد.

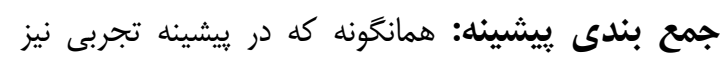

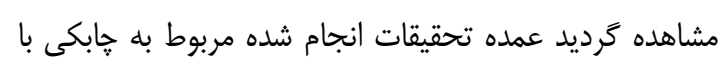

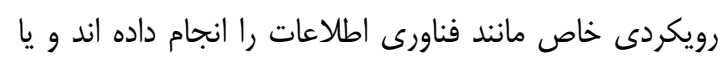

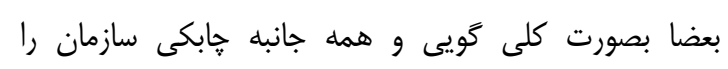

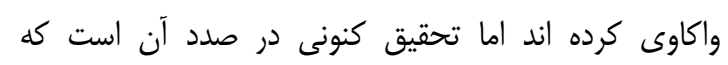
بصورت جزيى تر عواملى كه موجب هابكى بانك سيه استان

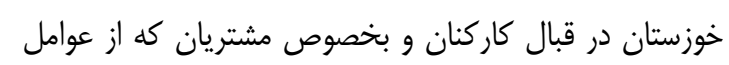

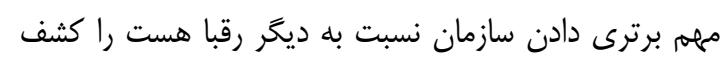

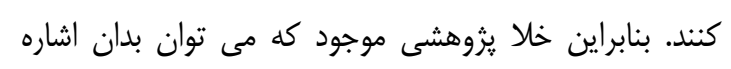

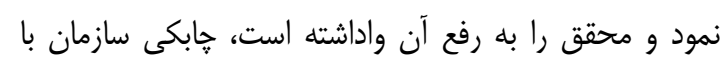

$$
\text { رويكرد توجه به كاركنان و مشتريان مى باشد الند }
$$

\section{ع.روش تحقيق}

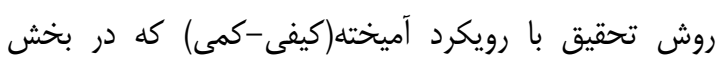

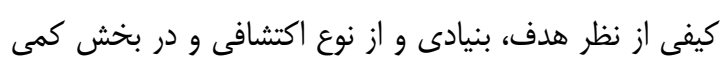

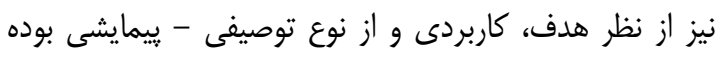

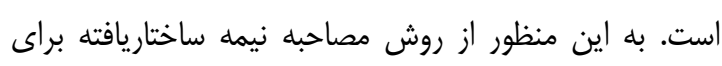

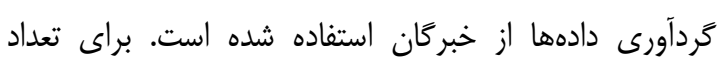

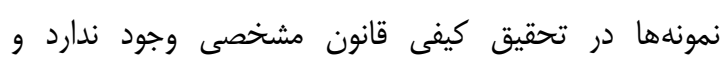

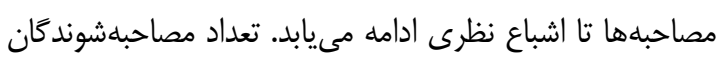

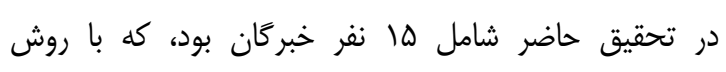

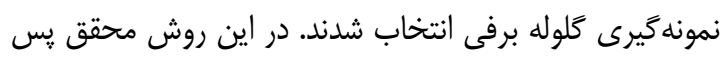

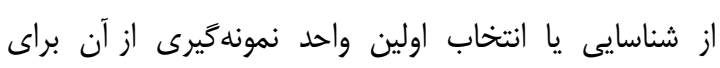

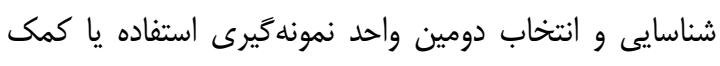

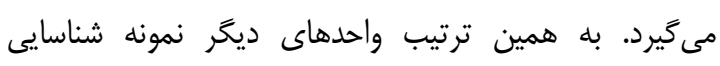

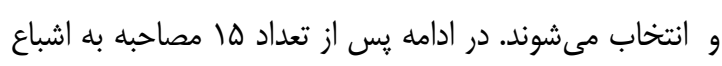

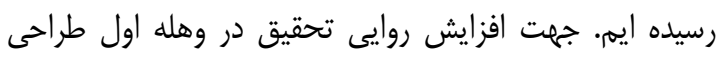

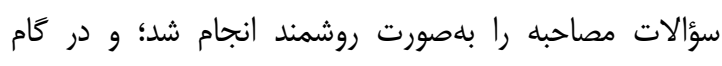

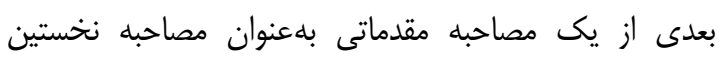

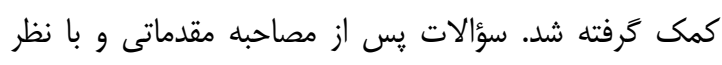

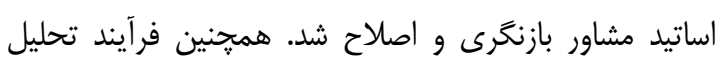

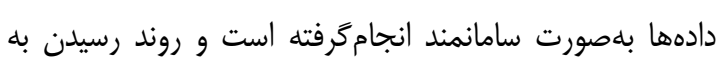

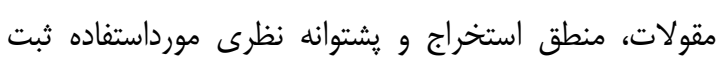

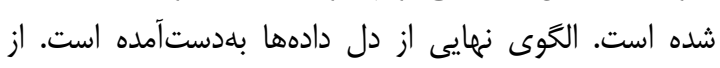

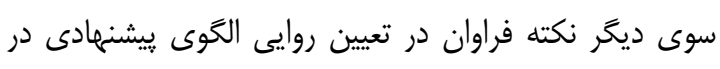

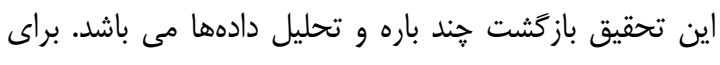

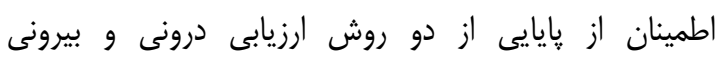




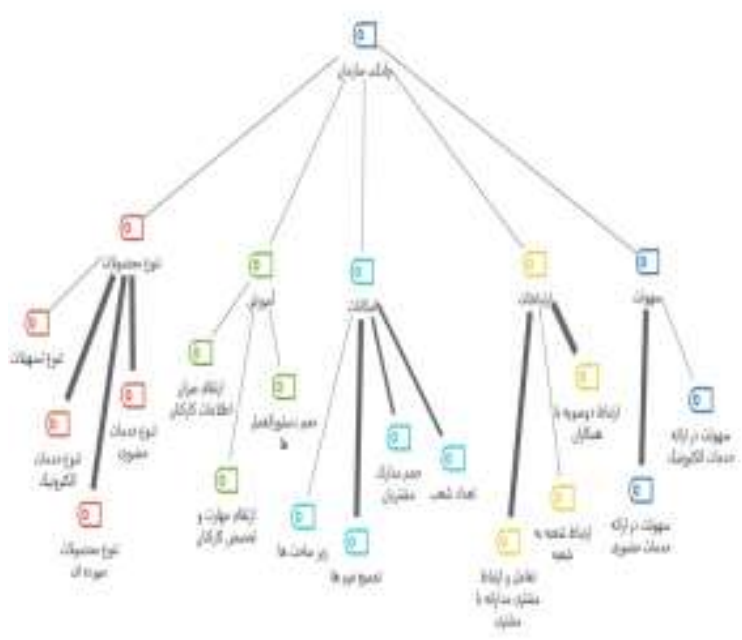

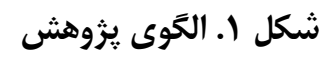

קابكى در در بانك سيه داراى مولفه هاى زير است :

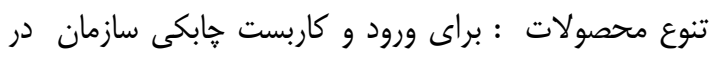

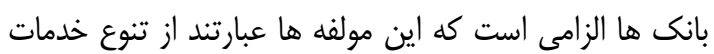

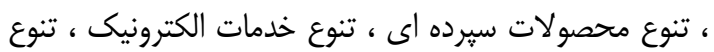

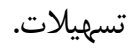

آموزش: براى ورود و كاربست خابكى سازمان در بانكى ها

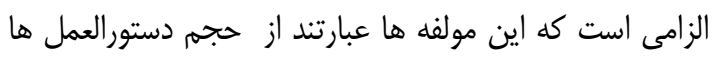

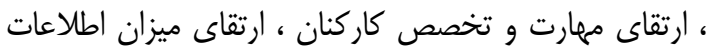
كاركنان. - ماك.

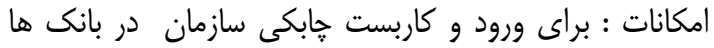

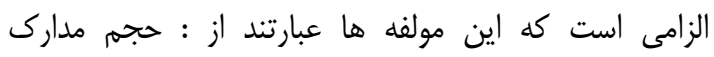

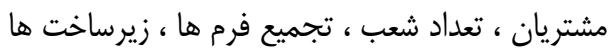

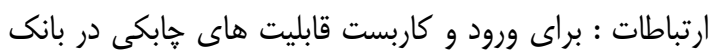

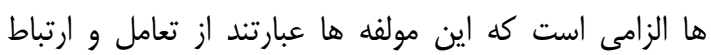

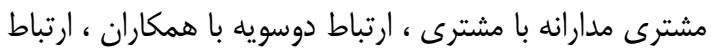
شعبه بله شعبه. سهولت : براى ورود و كاربست حابكى سازمان در بانكى ها الزامى است كه اين مولفه ها عبارتند از سهولت سارنات دران در ارائه

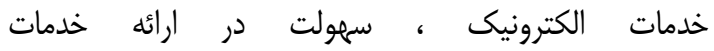
حضورى(تسهيلات ، سيرده و غيره) تحليل داده هاى كمى يس از بدست آمدن مدل تحقيق، يرسشنامه ها در بين
0.يافته ها 1-0-بخش اول: تحليل داده هاى كيفى

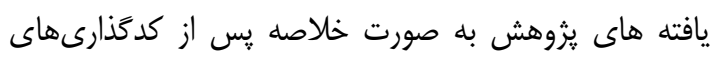

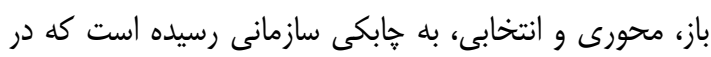

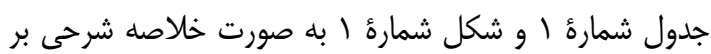
جَّونگى كدها ارائه شده است.

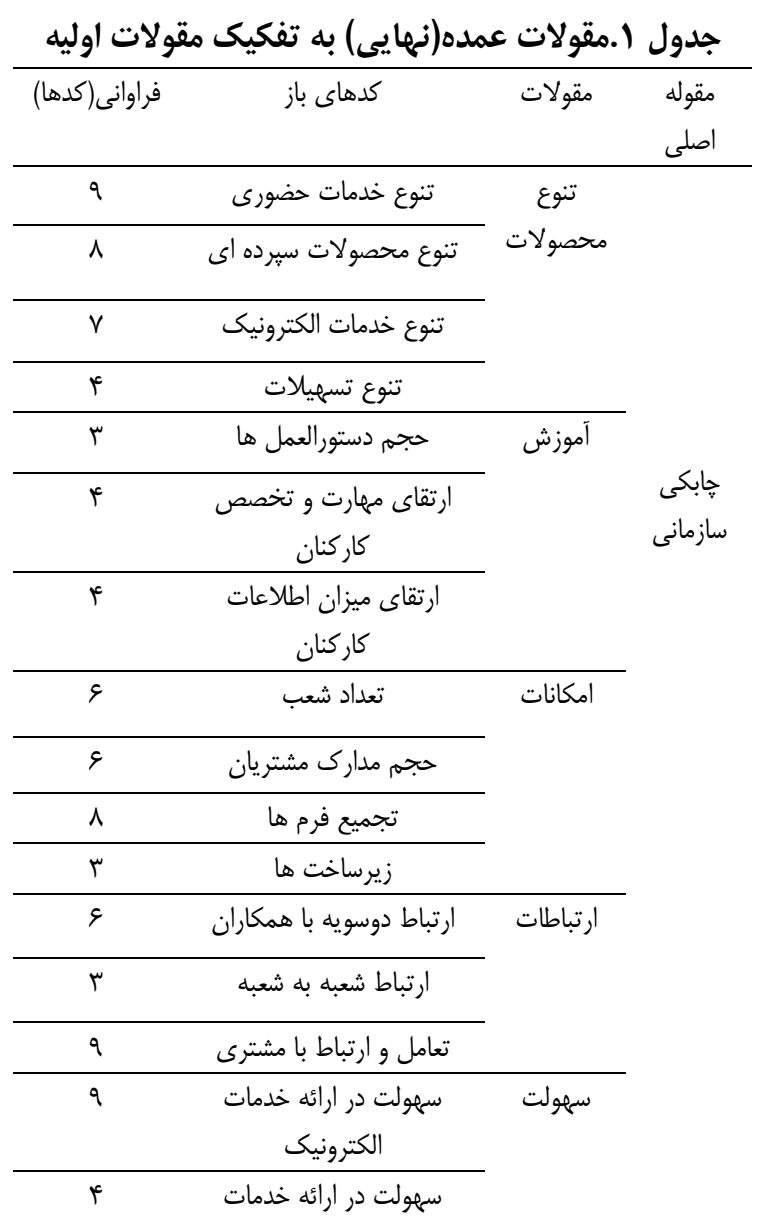

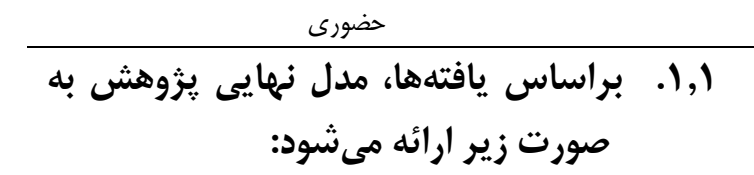


كاركنان توزيع كَديد و يس از بازَّت آنها جهت تحليل وارد

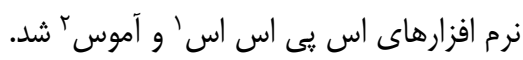

برازش مدل اندازه تَيرى و ساختارى

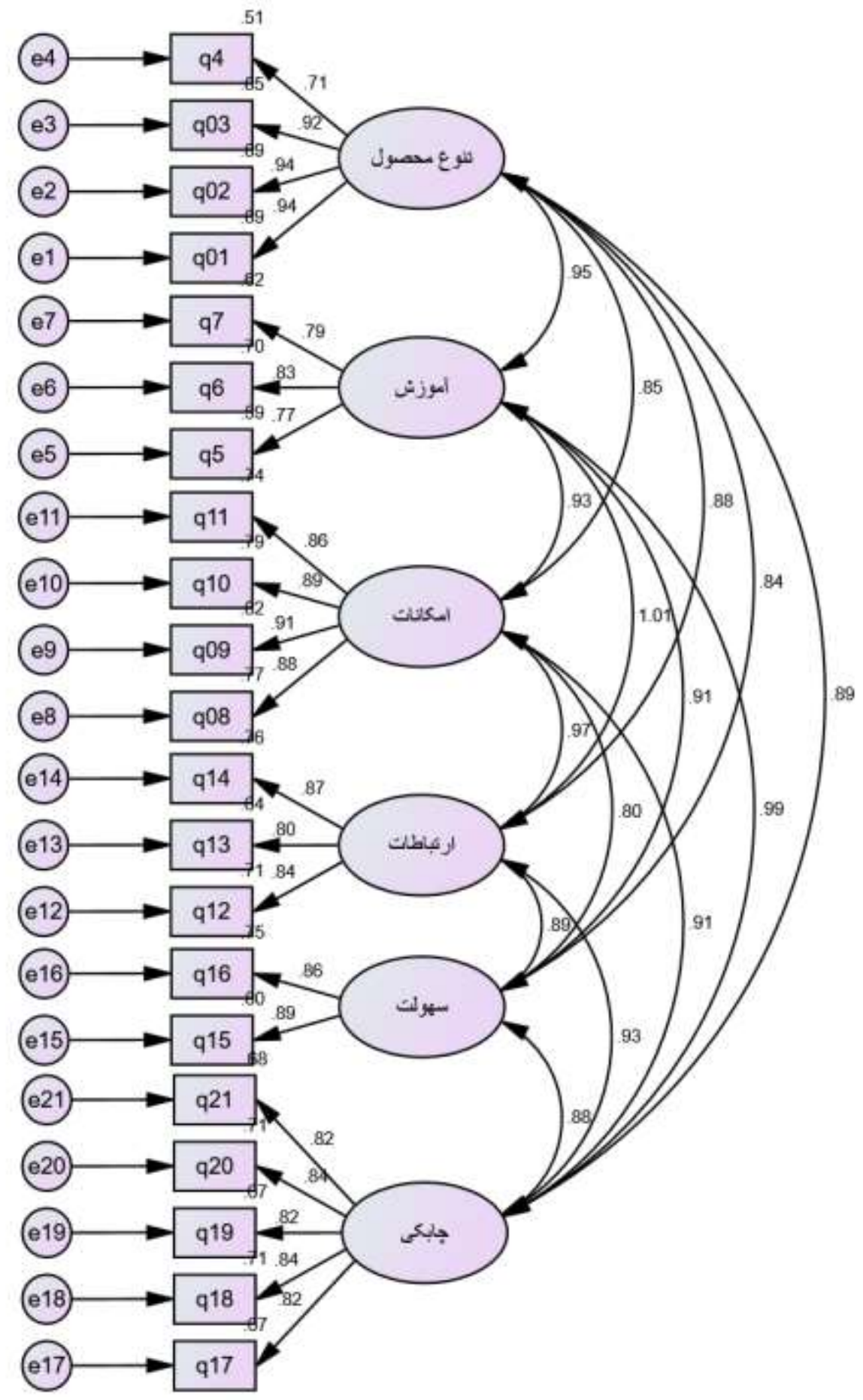



شكل ا. مدل اندازه كَيرى تحليل عاملى تاييدى متغيرهاى

شكل r. مدل ساختارى يزوهش(تخمين استاندارد)

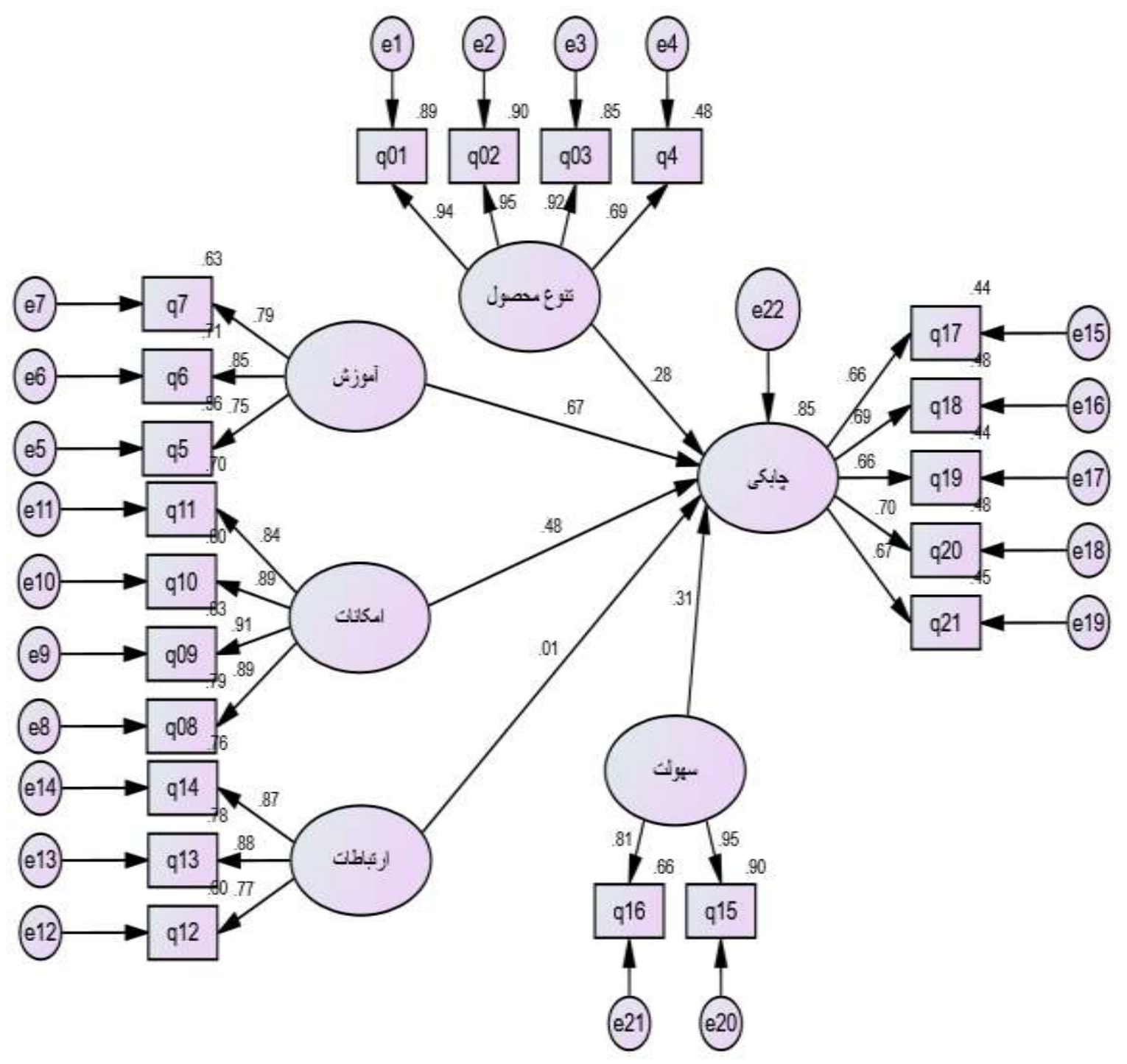

جدول - شاخصهاى برازش مدل ساختارى 
فf فلنامه علمى رهيافتى در مديريت بازر كانى، دوره ז، شماره r، تابستان ..

$\begin{array}{llllllllllll}\text { RMSEA } & \text { PRATIO } & \text { PNFI } & \text { PCFI } & \text { IFI } & \text { TLI } & \text { NFI } & \text { CFI } & \text { GFI } & \text { AGFI } & \text { X2/df }\end{array}$

\begin{tabular}{|c|c|c|c|c|c|c|c|c|c|c|c|}
\hline$<\cdot, \wedge$ & $>\cdot, \Delta$ & $>\cdot, \Delta$ & $>\cdot, \infty$ & $>, q$ & $>\cdot, 9$ & $>\cdot, q$ & $>\cdot, q$ & $>\cdot, q$ & $>\cdot, \wedge$ & $<\mu$ & معيار \\
\hline & & & & & & & & & & & ييشنهاد \\
\hline$\cdot, \cdot \cdot 1$ & $\cdot, V 11$ & .990 & $.9 \vee \wedge$ & $\cdot, 94$ & •,१९९ & •, १४९ & -, १४s & -,Q人र & $\cdot, \Delta V^{c}$ & Y,YM & مدل \\
\hline
\end{tabular}

مطابق جدول شماره r، شاخصهاى مدل تحقيق نيز نشان داد كه مدل از برازش مناسبى برخوردار است

آزمون فرضيات

جدول ب-ضرايب رتر سيونى و سطح معنادارى آنها

\begin{tabular}{|c|c|c|}
\hline نتيجه آزمون & دارى سطح معنى & 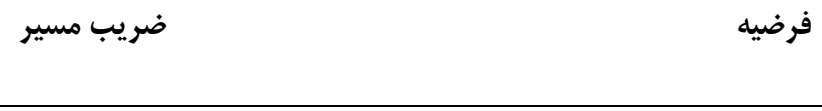 \\
\hline & & 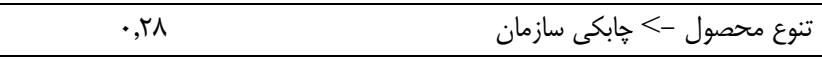 \\
\hline تأييد فرضيه & $\cdot, \cdots$ & \\
\hline تأييد فرضيه & $\cdot, \cdots$ & $\cdot, \uparrow$ \\
\hline رد فرضيه & $\cdot, 91 \wedge$ & زمان \\
\hline 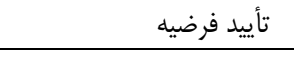 & $\cdot, \cdot \Delta$ & 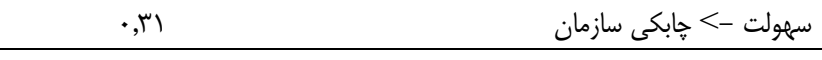 \\
\hline \multicolumn{2}{|r|}{ اطمينان 99 درصد معنادار مى باشد). } & به منظور سنجش روابط داخل مدل از ضرايب ركرسيونى \\
\hline \multicolumn{2}{|c|}{ بنابراين مطابق جدول شماره س، كليه متغيرهاى تحقيق به جز } & استاندارد شده استفاده مى شود. ضرايب استاندارد شده عددى \\
\hline \multicolumn{2}{|c|}{ متغير ارتباطات بر خابكى سازمان تاثير مثبت و معنادارى دارند. } & بين ا- تا I+ است. جنانجه ضريب استاندارد به عدد صفر \\
\hline \multicolumn{2}{|r|}{ 7-بحث و نتيجه تَيرى } & نزديك باشد يعنى تاثير كذارى متغير ناجيز است. اكر ضريب \\
\hline \multicolumn{2}{|c|}{ يكى از خارجوب هايى كه در جهت ارتقاى سرعت، انعطاف } & استاندارد به عدد ا نزديك باشد يعنى تاثير كذارى متغير مثبت \\
\hline \multicolumn{2}{|c|}{ يذيرى و كيفيت لازم در سازمان بكار مى رود خابكى سازمان } & و هم جهت با متغير وابسته است. اكر ضريب استاندارد به عدد \\
\hline \multicolumn{2}{|c|}{ است. كَاهى در سازمان ها نيازى به تغيير و دكرَّونى نيست } & ا- نزديك باشد يعنى تاثيركذارى متغير منفى و معكوس با \\
\hline \multicolumn{2}{|c|}{ 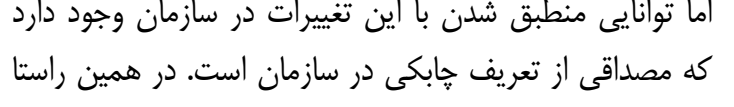 } & متغير وابسته است. براى سنجش معنادارى ضرايب استاندارد از \\
\hline \multicolumn{2}{|c|}{ يثوهش حاضر با هدف شناسايى عوامل بوجود آورنده هابكى } & نسبت بحرانى(CR) و سطح معنادارى استفاده مى شود: \\
\hline \multicolumn{2}{|c|}{ سازمان در بانك سيه استان خوزستان با رويكرد آميخته } & جنانجه نسبت بحرانى(CR) بيشتر از وه/ باشد ضريب \\
\hline \multicolumn{2}{|c|}{ صورت گرفت. يزوهش حاضر با استفاده از روش شناسى } & ركرسيونى در سطح اطمينان ه9 درصد و קֶنانجه نسبت \\
\hline \multicolumn{2}{|c|}{ يزوهش آميخته(كيفى-كمى) مورد تحليل قرار كرفت. در } & بحرانى(CR) بيشتر از T/DV باشد ضريب ركرسيونى در سطح \\
\hline \multirow{2}{*}{\multicolumn{2}{|c|}{ 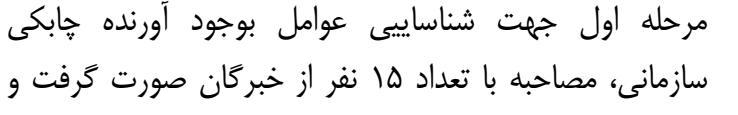 }} & اطمينان 99 درصد معنادار مى باشد. حنانجه سطح معنادارى \\
\hline & & كمتر هـ/• باشد ضريب ركرسيونى استاندارد شده در سطح \\
\hline \multicolumn{2}{|c|}{ با استفاده از روش تحليل كيفى، يرسشنامه اى طراحى شد كه } & 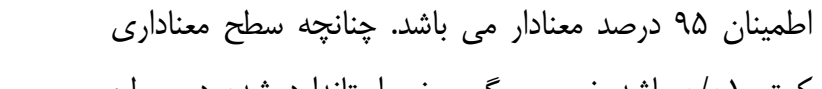 \\
\hline \multicolumn{2}{|c|}{ 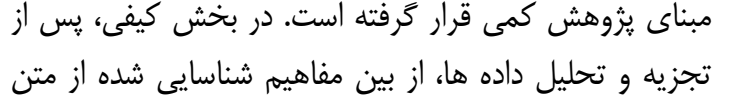 } & 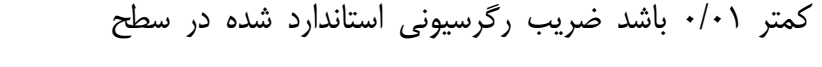 \\
\hline
\end{tabular}


مىتوانند تغيير قابل توجهى را در تمركز، تنوع بخشى و

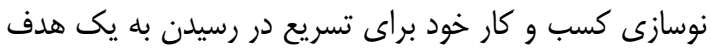

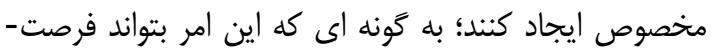

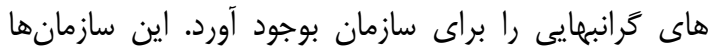

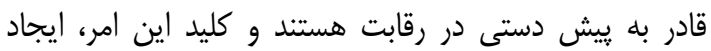
يكى برنامه ى راهبردى است كه نقشه وسيعى از توانيايىها،

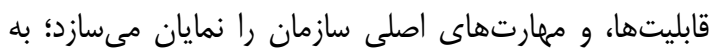

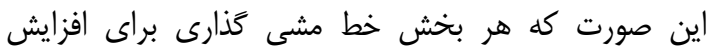

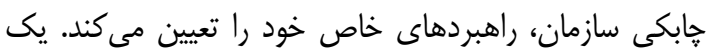

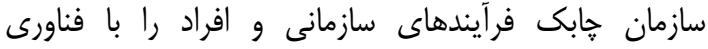

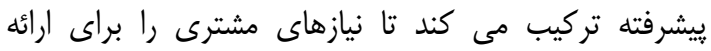

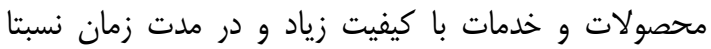

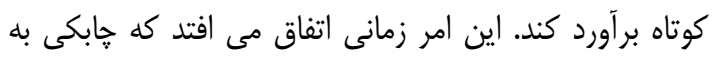

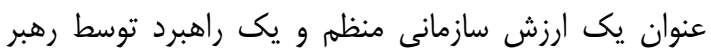

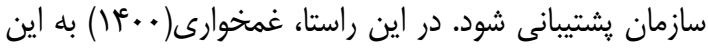

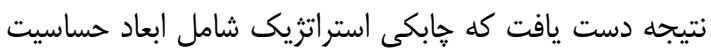

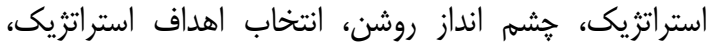

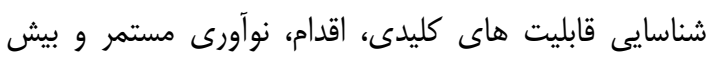

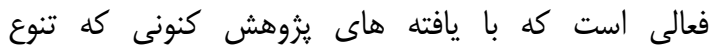
محصولات، تنوع خدمات، تنوع تسهيلات است همسو بودها

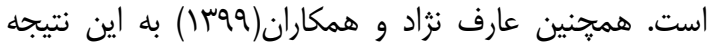
دست يافتند كه مؤلفه هاى انعطاف يذيرى وظيفه اي، مهارتى نئ و رفتارى به ترتيب از بيشترين نقش در تبيين קابكى سازمان

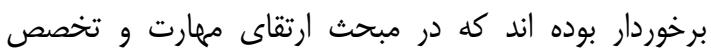

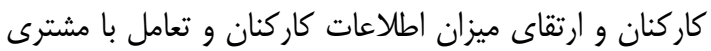

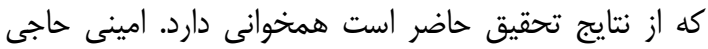

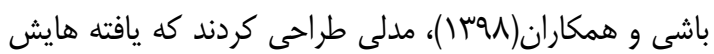
شامل 1-شناسايى مؤلفه هاى جابكى رهبرى منابع انسانى ، rيافتن نتايج و ييامدهاى حاصل از هابكى رهبرى منابع انسانى ، ب- شناسايى روابط بين مؤلفه ها و دست يافتن به

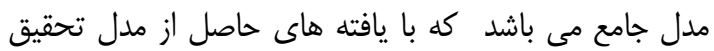

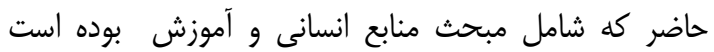
همسو مى باشد. مدل قانع عبادى و همكاران(1) هوبا)، شامل

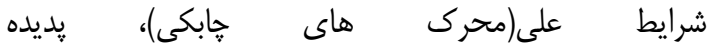

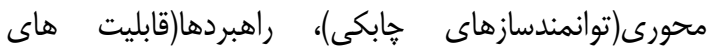

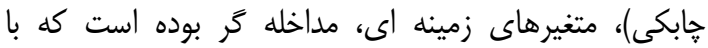
مولفه آموزش و ارتباطات در تحقيق حاضر همراستا بوده است.
مصاحبه، عا مورد به عنوان مهم ترين مؤلفه هاى مدل انتخاب و در قالب مقوله هاى مدل نظرى دسته بندى شدان مداند. براين اساس بر مبناى كدكذارى باز صورت كَرفته مفاهيم

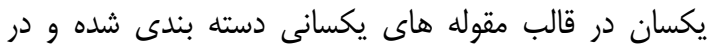
مجموع مؤلفه ها در قالب ه مقوله طبقه بندى شده اندان اند. در

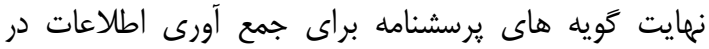

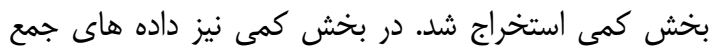

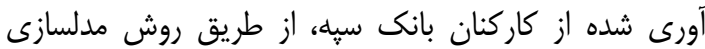

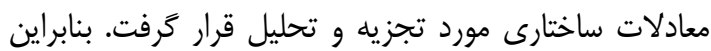
در بخش كيفى پاسخ به اين سؤال كه عوامل مؤثر بر هابكى

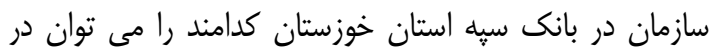
ينج حوزه تنوع محصولات، آموزش، امكانات، ارتباطات و و

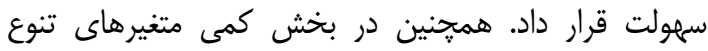
محصول، آموزش، امكانات و سمهولت بدليل داديل آنكه نسبت بحرانى بدست آمده هركدام بالاتر از ميزان حد مدان مجاز يعنى

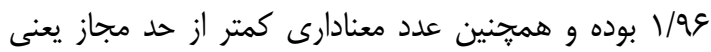
هـ/ بوده است، بر هابكى سازمان تاثير مثبت و معنادارى إنى

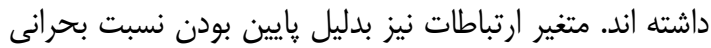

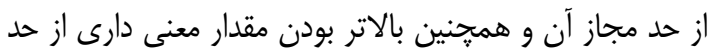

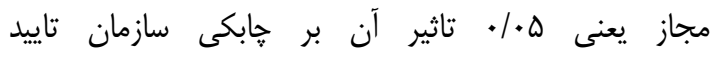
نشد.براساس اين نتايج مى توان اين كَونه استنباط كرد كه إنهان

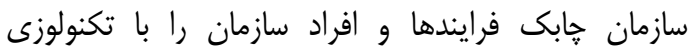
ييشرفته همخام ساخته و نياز هاى مشتريان را بر اساس ارائه

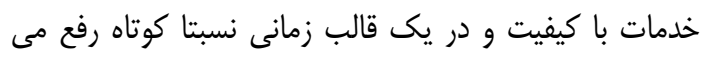
كند . حابكى به طور دائم به عملكرد يرسنل و سازمان، ارزش

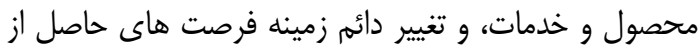

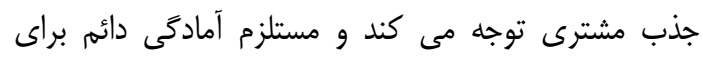
رويارويى با تغييرات بنيادى و سطحى است و سازئ كان وان هاى

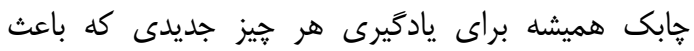

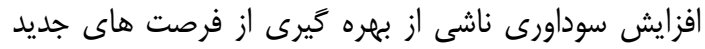

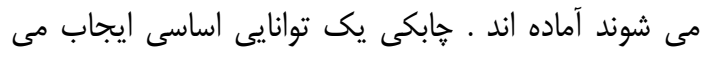
كند تا سازمان بتواند تغييرات موجود در محيط ران را احساس، دريافت، ملاحظه، تجزيه و تحليل و وييش بينى كند . بدين ترتيب، سازمانى خابك است كه ديدًاه وسيعى در مورد نظهم

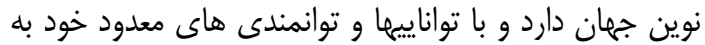

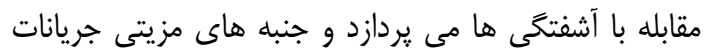
تغيير را تسخير مى كند. در واقع سازمانهاى هابنى هابك به آسانى 


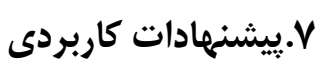

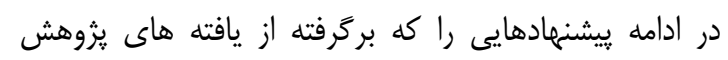
است، مطرح مى شود:

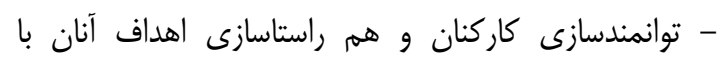
اهداف بانك از طريق ايجاد بستر و فرصت هاى لازم إن براى كاركنان جهت عرضه بهترين و كاراترين منابع فكرى در زمينه

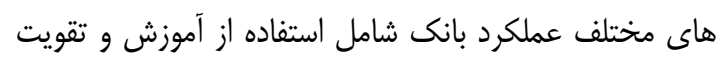

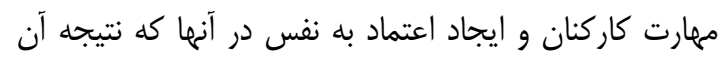
كاركنان را قادر مى سازد در شرايط مختلف سازمان، بهترين

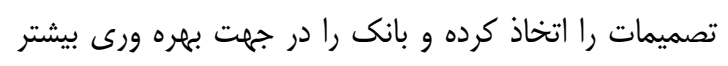

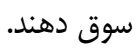
r-انتخاب مديران و عوامل آنها با هوشمندى بالا كه بتواند در

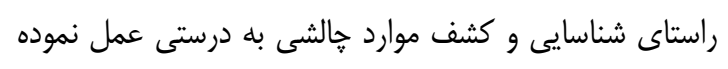

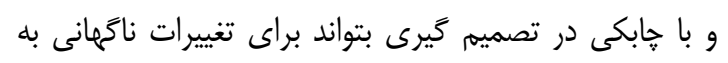

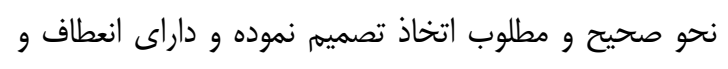

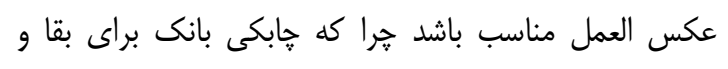
رشد در يك محيط رقابتى و محيطى با تغييرات مستمر و

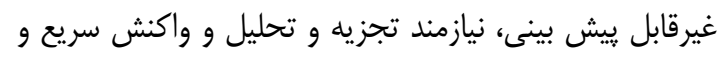

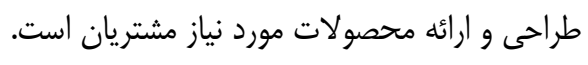
س-در راستاى جابك سازى بانى از طريق تأمين امكانات،

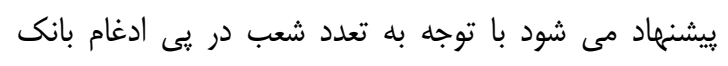
هاى نظامى در بانك سيه، نسبت به ابقا شعب تود كارا و

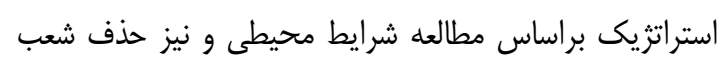

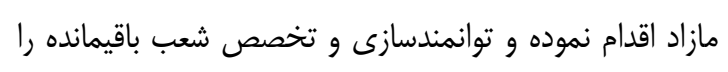

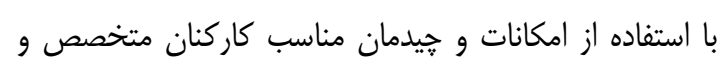
ظرفيت هاى موجود ارتقا داد.

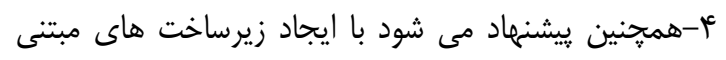

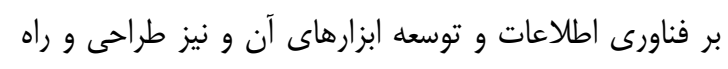

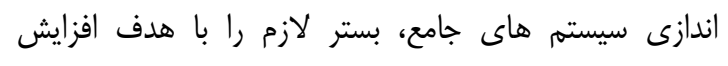
هابكى بانك و كسب رضايت مشتريان و كاركنان در ارائه هرجه بهتر، سريعتر و كاملتر خدمات فراهم ساخت. ه-هيشنهاد مى شود از طريق آموزش و ارتقاى دانش مديريت

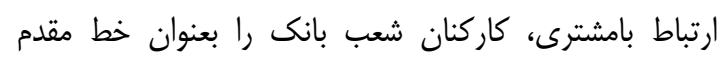

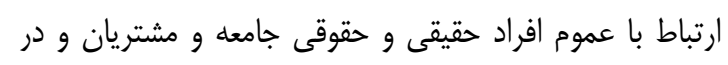

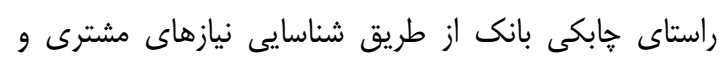

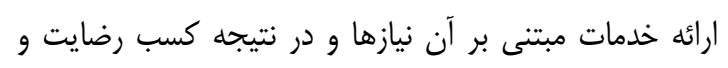
نيز موفقيت در بازار رقابت، تجهيز نمود.

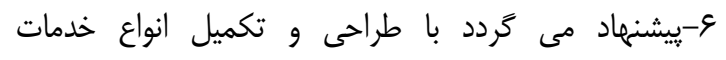
الكترونيك و غيرحضورى براى مشتريان از طريق دركاه ها و
جعفرزاده زرندى و همكاران(9V)، مدلى طراحى كردند كه

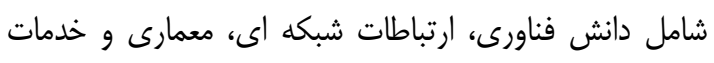

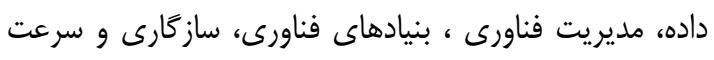

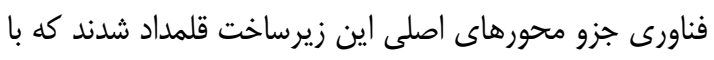
مولفه هاى تنوع محصولات، امكانات همسو بوده است. يافته

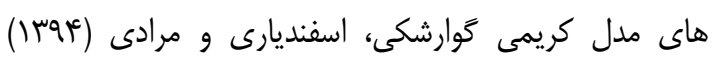
شامل خابكى پاسخ گويى مديريت، جابكى مديريت توليد،

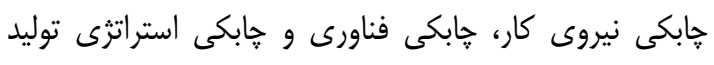

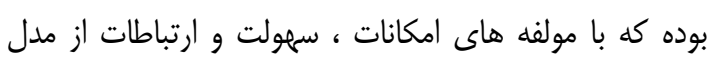
تحقيق حاضر مطابقت دارد. مدل آقايى و آقايى (سوسا) شامل

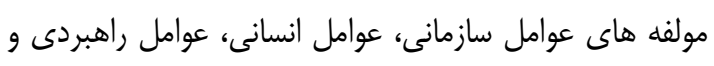

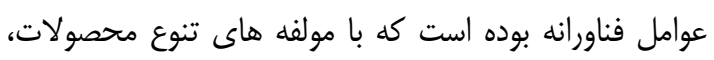
آموزش، امكانات، ارتباطات و سهولت از مدل تحقيق حاضر

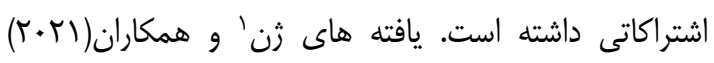
شامل تأثير بهره بردارى و بكارگيرى فناورى اطلاعات بر دانئ جابكى سازمان كه با مولفه هاى حاصل از نتايج تحقيق حاضر بردي يعنى زيرساخت ها و سهولت ارائه خدمات الكترونيك در يكى إنى إنى

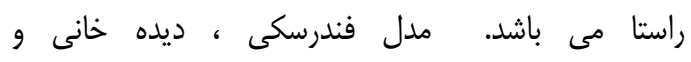

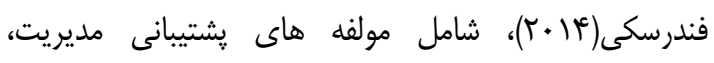

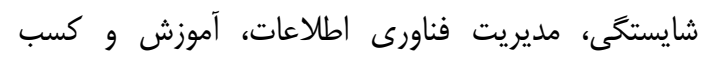

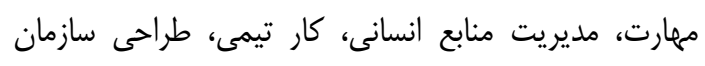

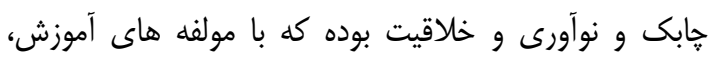
ارتباطات، امكانات و سهولت همسو بوده است. شريفى و وانى

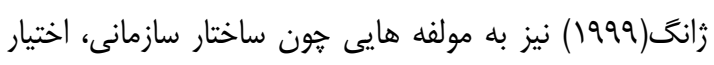

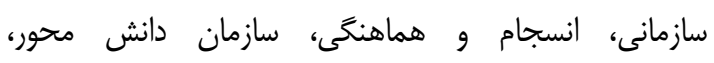

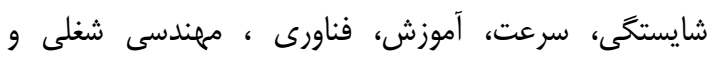

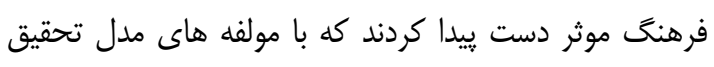
حاضر همجون تنوع محصولات، آموزش و ارتباطات همراستا بوده است.به طور كلى شناخت عوامل و ارائه راهكارها براساس موانع موجود كمى شايانى به برنامه ريزى و تصميم گيرى در خصوص رفع نقاط ضعف سازمان و تقويت نقاط موان مودان قوت و دست يابى به خابك شدن سازمان خواهد داشت دان.

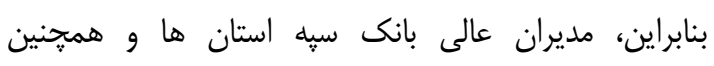

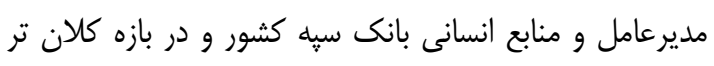
ديخر بانك هاى كشور، با استناد به نتايج اين تحقيق و باني إنائ تاكيد بر رعايت اصول و استانداردهاى اخلاقى و از ميان برداشتن موانع و فراهم كردن شرايط مطلوب براى كاركن

كام موثرى در دست يابى به خابك شدن سازمان بردارند. 
حسن رشيدى و همكاران : شناسايى عوامل بوجود آورنده جِابكى در بانك سِه استان خوزستان با رويكرد آميخته

نرم افزارها و بسترهاى مختلف موجود در كشور و در نتيجه

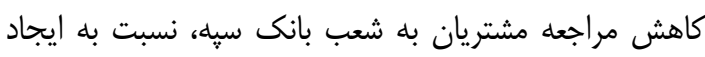

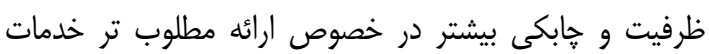
تخصصى تر مانند ايجاد تعهدات و تسهيلات و غيره در سطح شعب اقدام شود. 


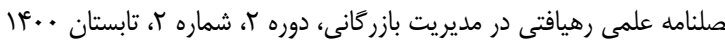

$$
\begin{aligned}
& \text { صنعت بانكدارى، فصلنامه مطالعات منابع انسانى، دوره . 1. }
\end{aligned}
$$

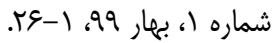

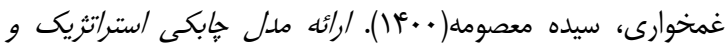

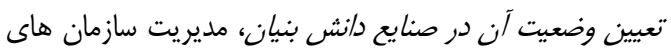

$$
\begin{aligned}
& \text { دولتى، q(T)، } \\
& \text { قانع عبادى، مليحه؛ آراسته، حميدرضا؛ نوه ابراهيه، عبدالرحيم و }
\end{aligned}
$$

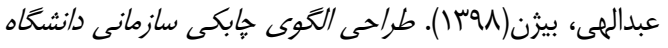

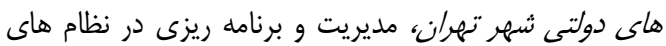

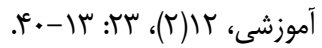

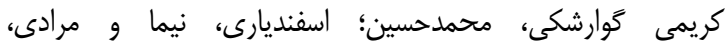

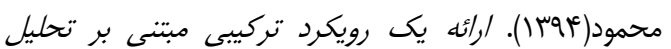

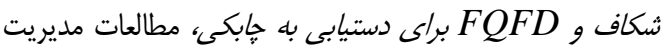

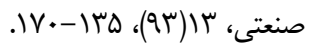

Cheng, C., Zhong, H. Cao, L.(2020). Facilitating speed of internationalization: The roles of business intelligence and organizational agility, Journal of Business Research, 110(2020), 95-103.

Darvishmotevali, M., Altinay, L. Koseoglu, M.A.(2020). The link between environmental uncertainty, organizational agility, and organizational creativity in the hotel industry, International Journal of Hospitality Management, 87(2020), 1-9.

Deng, Ch.P., Wang, T., Teo, S.H.T. \& Song, Q.(2021). Organizational agility through outsourcing: Roles of IT alignment, cloud computing and knowledge transfer, International Journal of Information Management, v60, octobr2021,102-125.

Ebrahimpour, H., Salarifar, M. \& Asiaei, A.( 2012).The Relationship between AgilityCapabilities and Organizational Performance: a Case Study among Home Appliance Factories in Iran, European Journal of Business and Management, 4(17):186-195.

Fendereski, A., Didehkhani, H., \& Fendereski, A.(2014). The Identification and Ranking Related to Organizational Agility Using Analytic Hierarchical Processing. International journal of Basic Science \& Applied Research, 3(7), 455-464.

Gjerald, O., \& Lyngstad, H. (2019). Service risk perceptions and risk management strategies in business-to-business tourism partnerships. Tourism management perspectives, 13, pp 717.

Lanti, M.(2016). Developing a lean and agile work force, Human Factors and Ergonomics in Manufacturing, 7 (1): 11-20.

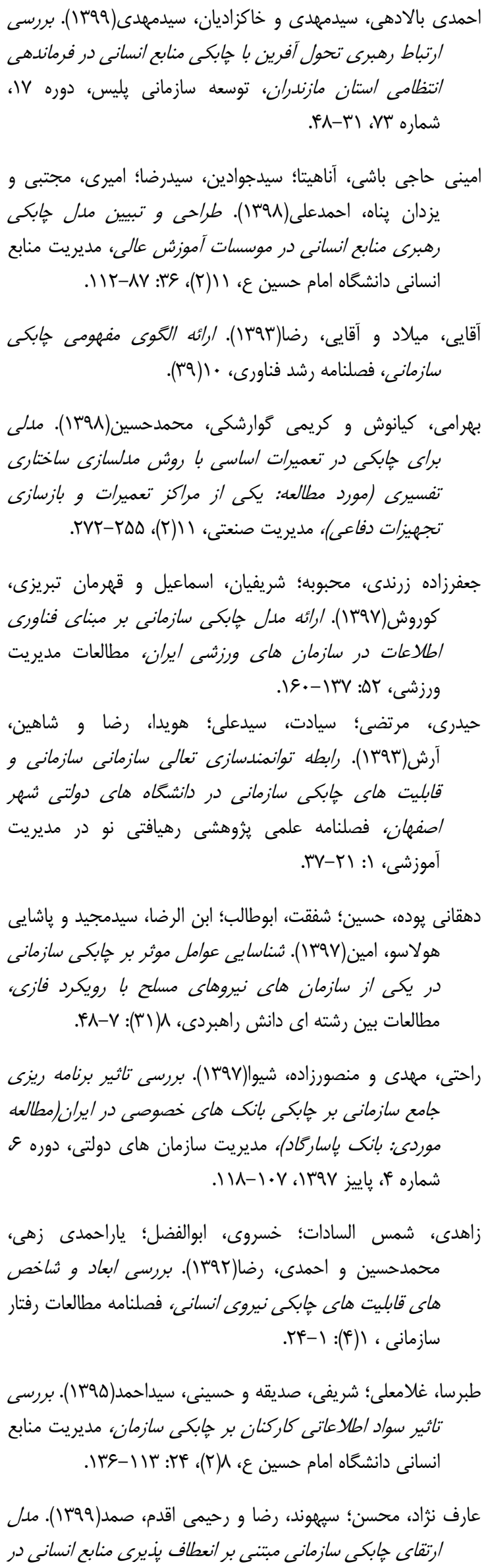


حسن رشيدى و همكاران : شناسايى عوامل بوجود آورنده جابكى در بانكك سيه استان خوزستان با رويكرد آميخته

Lee, J. (2001), A Grounded Theory: Integration and Internalization in ERP Adoption and Use, Unpublished Doctoral Dissertation, University of Nebreska, In Proquest UMI Database.

Maskell, B. (2012). The age of agile manufacturing, Supply Chain Management: An International Journal, 6(1).

Qin, R. \& Nembhard, D.A .(2010). " Workforce Agility for Stochastichally diffused conditionsA real options Perspective". Int.J.Production Economics, 125(2010) : 324-334.

Ravichandran.T.(2018). Exploring the relationships between IT competence, innovation capacity and organizational agility, The Journal of Strategic Information Systems, 27(1),22-42.

Zhen, J., Xie, Z. \& Dong, K.(2021). Impact of IT governance mechanisms on organizational agility and the role of top management support and IT ambidexterity, International Journal of Accounting Information Systems, V40, March2021, 100-115. 